\title{
THE EFFECT OF LOW CORPORATE TAX RATE ON PAYROLL TAX EVASION
}

\section{Boryana Madzharova}
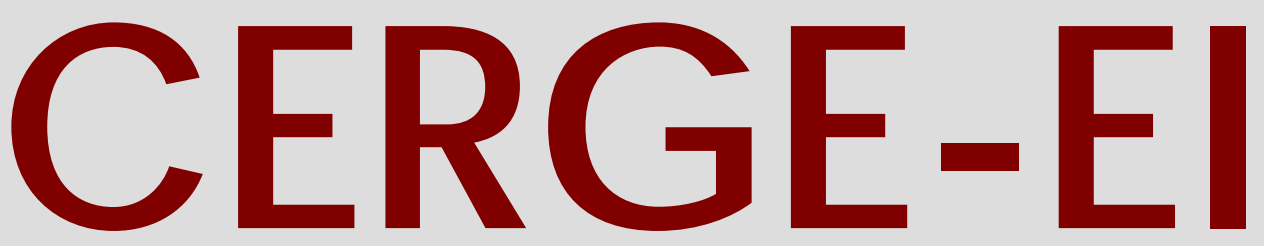

Charles University CenterforEconomic Research and Graduate Education Academy of Sciences of the Czech Republic Ec onomic Institute 


\title{
Working Paper Series 448 (ISSN 1211-3298)
}

\section{The Effect of Low Corporate Tax Rate on Payroll Tax Evasion}

\author{
Boryana Madzharova
}

\author{
CERGE-EI \\ Prague, September 2011
}
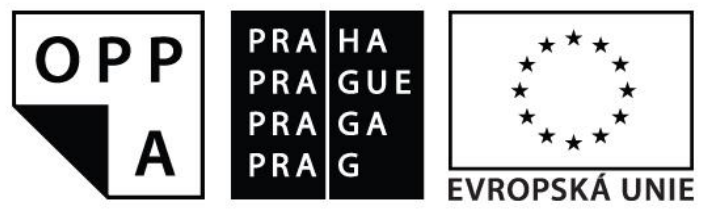

EVROPSKÝ SOCIÁLNÍ FOND

PRAHA \& EU: INVESTUJEME DO VAŠÍ BUDOUCNOSTI 
ISBN 978-80-7343-251-5 (Univerzita Karlova. Centrum pro ekonomický výzkum a doktorské studium)

ISBN 978-80-7344-243-9 (Národohospodářský ústav AV ČR, v.v.i.) 


\title{
The Effect of Low Corporate Tax Rate on Payroll Tax Evasion*
}

\author{
Boryana Madzharova ${ }^{\dagger}$
}

\begin{abstract}
It is a commonly held view that the widespread policy of cutting the corporate income tax has a positive effect on taxable income through decreasing firms' incentive to hide profits. A neglected side of this policy, however, is its potential to trigger more evasion in other tax bases, such as the social security base, especially if the corporate income tax rate is low compared to the payroll rate. We develop a model in which employers and employees cooperate in declaring lower wages to the tax authorities in order to evade payroll contributions. Since wages and payroll taxes are a deductible expense for firms, a lower reported wage translates into higher corporate profits on paper and hence, shifting of tax liability out of social security into the corporate tax base. Using firm-level panel data for Bulgaria, where the problem of contribution evasion is prevalent, we find that a $1 \%$ increase in the net-of-tax-share of the corporate tax rate reduces reported wages in the economy by $.21 \%$, but leads to higher taxable incomes. An identical increase in the payroll net-of-tax-share results in a $.28 \%$ rise in wages. Thus, even though the separate tax bases respond significantly to changes in the corporate tax rate, the impact on the combined tax base of wages and taxable incomes is estimated to be small.
\end{abstract}

Keywords: Corporate tax, Payroll tax, Evasion, Wage underreporting JEL Classification: H25; H26; H55; J3

${ }^{*}$ I wish to thank Libor Dušek, Peter Katuščák, and seminar participants at Potsdam University, Ruhr University of Bochum, CESifo Venice Summer Institute and the University of Copenhagen for useful comments. Any remaining errors are mine.

${ }^{\dagger}$ CERGE-EI is a joint workplace of the Center for Economic Research and Graduate Education, Charles University, and the Economics Institute of the Academy of Sciences of the Czech Republic. Politickych veznu 7, 11121 Prague 1, Czech Republic, e-mail: Boryana.Madzharova@cerge-ei.cz. 


\begin{abstract}
Abstrakt
Všeobecně se má za to, že snižování daně z př́ijmů korporací má pozitivní dopad na jejich zdanitelný příjem, protože snižuje podněty firem ke skrývání zisků. Opomíjenou stránkou tohoto prrístupu je jeho potenciál způsobit další úniky v jiných daňových základech, jako například daň ze sociálního zabezpečení, zejména pokud korporátní daň z př́ijmů je nízká ve srovnání s daní z mezd. Vytváříme model, v kterém zaměstnavatelé a zaměstnanci spolupracují přivnazování nižších mezd daňovým úřadům, aby se vyhnuli srážkám z mezd. Protože mzdy a srážky z mezd jsou daňově uznatelným nákladem pro firmy, nižší vykazované mzdy znamenají i vyšší daňový základ daně z př́ímu. Tento přesun daňové zátěže testujeme s pomocí panelových data na úrovni firem v Bulharsku, kde se problém těchto daňových úniků často vyskytuje. Zjišt'ujeme, že $1 \%$ nárůst části mezního př́ijmu, který firmám zůstává po zdanění (tj. 1-t) u korporátní daně snižuje reportované mzdy v ekonomice o $0,21 \%$, ale vede k vyšším zdanitelným př́ijmům. Stejné zvýšení části mezního př́ijmu, který firmám zůstává po zdanění u srážek ze mzdy vede k 0,28\% nárůstu v mzdách. Ačkoliv jednotlivé daňové základy reagují významně na změny v zdanění korporací, snížení korporátní daně má jen malý dopad na kombinovaný daňový základ mezd a zdanitelných příjmů.
\end{abstract}




\section{Introduction}

The evasion of social security contributions has been a long-standing problem in the countries of Latin America and Central and Eastern Europe (CEE). Crude estimates for some Latin American countries in the early 1990s show that 50\% to $60 \%$ of the contribution liability remained uncollected, with Brazil heading the list, while between $20 \%$ and $30 \%$ of total contribution income in CEE was evaded as estimated by the International Labour Office in the mid-1990s (Gillion et al., 2000). In 2002, for example, according to a number of surveys, approximately $34 \%$ of all employed in Bulgaria understated their true wages and $25 \%$ worked without an official labour contract (Dimitrov et al., 2004). Although pervasive in CEE and Latin America, payroll tax evasion is by no means limited to these regions. In fact, as Gillion et al. (2000) point out, this type of evasion poses a challenge even in the OECD countries, albeit on a smaller scale.

Not only does payroll tax evasion undermine the credibility and legitimacy of the social security system, but it also distorts labour markets by creating unfair competition and necessitating higher tax rates to generate required revenue (Pashev, 2005). Unlike tax evasion that affects the general functioning of government, contribution evasion directly impacts current pensioners' benefits and compliant contributors under the defined benefit (DB) scheme. It reduces aggregate savings and output and may result in the introduction of a minimum pension paid from general revenue in defined contribution (DC) systems with low personal savings (Manchester, 1999; Gillion et al., 2000). When achieved through the underreporting of wage earnings, contribution evasion tends to flatten the benefits structure, erodes the personal income tax (PIT) base and, depending on strategy, spreads out to other tax bases as well.

There are various ways for an employer to evade the payment of contributions. The principal strategies include failing to register an employee or registering him as a contractor/temporary worker, not remitting contributions to the authorities, underpaying withheld contributions, or underreporting wage payments (McGillivray, 2001; Bailey and Turner, 2001). In many countries employers are responsible for filing a tax return on behalf of employees in the absence of other personal income but the labour income. All of the above schemes, therefore, can be executed with or without the collusion of the employee.

Studying evasion is especially difficult due to its illegality and hence, lack of consistent data. Nevertheless, various theoretical and empirical studies, predominantly on personal income tax evasion, have emerged, primarily after 1972, when Allingham and Sandmo (1972) positioned evasion in a specific theoretical framework. Contribution evasion, 
however, remains largely unexplored in the economic literature.

In this article, we consider contribution evasion in conjunction with tax evasion accomplished through massive underreporting of labour income in Bulgaria over the 1997-2002 period. Throughout this period, direct taxes fell steadily, with the statutory corporate income tax (CIT) rate going down from $42.4 \%$ to $23.5 \%$ for big companies and from $33.4 \%$ to $23.5 \%$ for smaller businesses. Social security rates, however, exhibited a slight downward trend, from $44 \%$ in 1997 to $42.7 \%$ in 2002 . Yet, the reduction in direct taxes in Bulgaria did not translate into a narrower compliance gap, a fact largely attributed to the excessive burden of compulsory contributions (Pashev, 2005).

The most widespread means of evading contributions was the understatement of workers' real earnings, which triggered evasion in the PIT base too (Dimitrov et al., 2004). Since firms understated wages, they necessarily ended up with higher corporate profits because labour costs are a deductible expense. Thus, they faced a trade-off between overpaying CIT or paying full contributions. For the period 1997-2002, the CIT rate was significantly lower than the payroll tax rate, creating incentives for shifting out of the payroll base.

We develop a theoretical framework in which employers and employees cooperate in underreporting actual wages for tax purposes. As a result, employers decrease their payroll tax payments, while employees receive higher net wages. The workers' decision to forego future pension benefits for current income and the employers' choice to evade are discussed in the context of Bulgaria and the specificities of its economy, but to a large extent such analysis is applicable to any country with a weak tax administration, significant payroll tax rates relative to the corporate burden, and general public mistrust in authorities. The declaration of lower wage payments than incurred in reality increases the firm's taxable income (TI) and hence, profit tax liability. The employer, therefore, can decide to decrease TI through the manipulation of sales or other means in order to bring profit down to its actual level or to overpay corporate income tax, fully or partially. We then derive the relationships between the magnitude of fraud, the payroll and the CIT rates.

To find out whether there is indeed shifting of tax liability out of social security into the corporate tax base, we use firm-level panel data for Bulgaria from 1997 to 2002. In particular, we study the effect of the payroll and the CIT rate, and the difference between the two on reported wages and taxable incomes by firms. In the presence of income shifting, we would expect a positive effect of the corporate tax rate on reported wages and a negative effect of the payroll rate on taxable income. The effect of the tax wedge on wages should be negative, as an increase in the tax wedge makes income 
shifting out of the payroll base more profitable and hence, drives reported wages down. Even if only a fraction of firms decide to overpay corporate income tax as a result of their evasion activities in the social security base, the tax wedge should have a positive influence on reported taxable incomes in the corporate base. We exploit the two-rate CIT code until 2002, the annual cuts in the CIT, and the fact that different categories of labour are subject to different payroll contribution rates within and across years, as sources of variation in the tax rates.

Our results show that a $1 \%$ increase in the CIT net-of-tax-share reduces wages in the economy by $.21 \%$, but raises taxable incomes. Conversely, a $1 \%$ rise in the payroll net-of-tax-share results in $.28 \%$ higher reported wages. Due to these opposing effects, the overall impact of the changes in the corporate tax on the combined tax base of wages and taxable incomes is small, even though wages and TI individually respond considerably to fluctuations in the CIT rate.

The paper is structured as follows: Section 2 summarises the literature on contribution evasion; Section 3 presents the theoretical framework of analysis ; Section 4 provides an overview of the Bulgarian social security system and the major reforms over the period of interest as well as sketches the main features of the CIT law, while in Sections 5 and 6 we discuss the data, the empirical specification, and test the main hypotheses generated by the model; Section 7 evaluates the impact of the tax reforms on the full tax base and Section 8 concludes.

\section{Literature on Evasion}

The economic literature on contribution evasion is scant, even though there has been a significant discussion of the reasons, consequences and the possible strategies for fighting payroll tax evasion (Gillion et al., 2000; McGillivray, 2001; Bailey and Turner, 2001; Manchester, 1999). Theoretically, the issue of wage underreporting has been tackled in considerable detail by Gideon Yaniv in a series of papers in the context of personal income tax (Yaniv, 1988, 1992). Yaniv (1988) studies the advantages of withholding versus selfdeclaration for personal income taxation. In particular, he explores the possibilities of tax evasion in a withholding system, in which the employer remits employees' withheld PIT taxes to the authorities. The employer may choose not to comply by understating his total wage payments without the knowledge of his employees. Thus, the employer appropriates part of the personal income taxes of his employees, which he was supposed to transfer to the authorities. Yaniv assumes that the firm always overpays corporate income tax due to wage underreporting and if caught, will be either reimbursed or 
not. Therefore, the author imposes full shifting of tax liability from the personal to the corporate tax base, abstracting from other taxes, such as payroll tax, that are inevitably affected by this type of fraud mechanism.

Collaborated employer-employee evasion is explored in Yaniv (1992), again in the context of the PIT. The mechanism of cooperation is the following: The employer understates his wage payments and as a consequence overpays CIT. Because less PIT tax is withheld from employees, they agree to work for lower than the market wage in order to compensate their employer for the risk of being detected and the overstatement of his profit liability.

While PIT evasion is incorporated into the model developed in the current paper, it only arises as a consequence of payroll tax evasion. We consider a mechanism in which the market wage remains unchanged in reality, but is underreported for tax purposes. Accordingly, benefits to the employer and to workers accrue from lowering their payroll tax liability at the expense of the government, resulting in lower cost to the employer and higher net wages. Higher net wages for the worker further follow from the fact that a lower wage stated in the labour contract translates into a lower PIT payment.

Lastly, Yaniv (1993) examines the hiring of workers without a labour contract, which is yet another possible channel for payroll tax evasion. In this case the choice variable is the number of employees declared rather than their wage level. In this article we will not take this option into account but will focus entirely on wage understatement.

Recently, there have been a number of empirical papers on contribution evasion in Asia, and in particular, China. Nyland et al. (2006) make use of firm-level data of audited businesses in Shanghai who either paid their contributions in full, underpaid, or overpaid. They set out to determine the characteristics of firms who tend to underpay contributions and find that firm size plays a role in evasion. Their results show that in Shanghai big companies tend to evade more contributions relative to smaller firms.

Although not focusing on evasion, Gordon and Slemrod (2000) provide some empirical evidence on income shifting between the corporate and personal tax bases triggered by differences in the PIT and CIT rates. Using aggregated cross-sectional data, the authors estimate the effect of the difference in tax rates on both the corporate rates of return and labour compensation of individuals. Their regressions yield a positive statistically significant relationship between the PIT rate and the corporate rates of return, whereas this relationship is reversed for the CIT rate, signalling a strong case for income shifting.

If tax liability is shifted out of one base into another, then the decrease of income into the first base should be accompanied by an equal increase in income in the second 
base. Checking if this is indeed the case, Gordon and Slemrod (2000) find that a one percentage point increase in the difference between the CIT and PIT rates leads to a $3.4 \%$ rise in reported labour income in a pooled 2SLS regression.

The present paper considers the shifting of income from the social security system to the corporate tax base through the mechanism of wage underreporting. This shift may not be complete, in the sense that employers may choose not to report all sales and hence avoid overpaying profit taxes.

\section{The Model}

We develop a model in which the firm underreports its wage bill, while having the consent of its employees and shares the benefits of evasion with them. The firm simultaneously decides whether to overpay corporate profits, only part of the increase in profit, or none of it.

Let the true profit of the firm be $\pi^{r e a l}=Y\left(L^{*}\right)-w^{R} L^{*}-w^{R} L^{*} t_{s}$, where $w^{R}$ is the gross wage paid to the employee in the absence of fraud, $L^{*}$ is the number of workers, already optimally chosen by the firm, and $t_{s}$ is the payroll tax rate on the employer. ${ }^{1}$ $Y\left(L^{*}\right)$ is the value of output. Since the total wage bill depends both on the number of employees and their individual wages, we have assumed that the company has optimally chosen its number of employees and manipulates wages in order to adjust the total wage bill.

Denote $t_{e}$ to be the payroll rate on workers and $t_{p}$ the personal income tax rate. A non-evading firm pays $w^{R}\left(1+t_{s}\right)$ per employee, while a worker's after-tax earnings are $\left(1-t_{p}\right)\left(1-t_{e}\right) w^{R}$. If the firm underreports $w^{R}$ by an amount $u$, the gross wage for tax purposes becomes $w^{R}-u$. This type of evasion generates benefits from three different sources: Contributions payable by the firm decrease by $u t_{s} L^{*}, u t_{e} L^{*}$ is the fall in employees' contributions and finally, PIT revenue goes down by $t_{p}\left(1-t_{e}\right) u L^{*}$.

We do not introduce a bargaining mechanism between workers and employers for the redistribution of the above-mentioned gains. Before a person is hired, he needs to sign an employment contract stipulating his exact gross remuneration to be $w^{R}-u$, with the mutual understanding that he will actually receive $w^{R}$ with $u$ given under the table. The worker's net wage increases by $t_{p} u+t_{e} u\left(1-t_{p}\right)$, i.e. we assume that the savings realized due to evaded employee's contributions go back to the employee in the form

\footnotetext{
${ }^{1}$ Allowing for an endogenous number of employees, it can be shown that due to contribution evasion, the marginal cost of labor goes down, which makes it profitable to hire more workers. Even if the firm adjusts its number of workers, the incentive for contribution evasion (income shifting) is still present as long as the necessary condition for evasion, derived later on in eq.(9), holds.
} 
of higher compensation. In other words, if the total payroll rate is $30 \%$ divided into a 80:20 ratio between an employer and a worker, underreporting the wage by $1 \$$ results in a $24 \dot{c}$ gain for the employer and a $6 \dot{c}$ gain for the worker, ignoring the PIT benefit. The diagram below summarises the benefits of evasion to both parties:

$$
\begin{aligned}
& \text { No evasion: } \underbrace{w^{R}\left(t_{s}+1\right)}_{\text {cost to employer }} \longleftarrow w^{R} \longrightarrow \underbrace{\left(1-t_{p}\right)\left(1-t_{e}\right) w^{R}}_{\text {no-evasion net wage }} \\
& \text { Evasion (What is seen by authorities): } \\
& \underbrace{\left(w^{R}-u\right)\left(1+t_{s}\right)}_{\text {cost to employer }} \longleftarrow \underbrace{w^{R}-u}_{\text {authorities }} \longrightarrow \underbrace{\left(1-t_{p}\right)\left(1-t_{e}\right)\left(w^{R}-u\right)}_{\text {official net wage }} \\
& \text { Evasion (What happens in reality): } \\
& \underbrace{w^{R}+\left(w^{R}-u\right) t_{s}}_{\text {cost to employer }} \longleftarrow \underbrace{w^{R}}_{\text {real }} \longrightarrow \underbrace{w^{R}-\left(w^{R}-u\right)\left(t_{e}+t_{p}\left(1-t_{e}\right)\right)}_{\text {true net wage }}
\end{aligned}
$$

As the firm cannot report its true wage bill, the profit that it declares to the authorities is $\pi^{\text {reported }}=Y\left(L^{*}\right)-\left(w^{R}-u\right) L^{*}-\left(w^{R}-u\right) L^{*} t_{s}$. The real profit as a result of contribution evasion increases to

$$
\pi^{\text {real,evasion }}=Y\left(L^{*}\right)-w^{R} L^{*}-\left(w^{R}-u\right) L^{*} t_{s}>\pi^{\text {real }}
$$

The difference $\pi^{\text {reported }}-\pi^{\text {real }}=\left(1+t_{s}\right) u L^{*}$ constitutes an evasion-driven increase in profit that can be taxed at the corporate tax rate $t_{c}$. It is at this point that social security evasion creates incentives for further manipulation of taxable income in the corporate income tax base.

Without contribution evasion, reported taxable income is such that the marginal benefit of reporting one more dollar equals the marginal cost. The underreporting of wages artificially increases TI above its optimal level and the firm has an incentive to bring profit down. This is not a costless procedure, however, since manipulation of invoices, or whatever other method the firm chooses to hide the rise in profits, involves the risk of being caught. Moreover, an audit based on suspicions that a firm underreports wages can also uncover manipulation of profits, whether or not triggered by contribution evasion. In any case, contribution evasion increases the probability of audit in general, and hence the marginal cost of profit manipulation goes up, inducing profit overreporting.

Knowing by how much its profit rises on paper, a firm can choose to hide part of its sales or choose another strategy in order not to pay corporate income tax in excess of its true liability. ${ }^{2}$ Suppose that the firm subtracts a fraction $\phi u L^{*}\left(1+t_{s}\right)$ from its

\footnotetext{
${ }^{2}$ Some firms may deliberately decide to overpay CIT in a given year, especially if they have understated
} 
taxable income. Thus, if $\phi=0$, there is no attempt to bring profit down to its true level and part of the losses in social security revenue are mitigated by more collections in the corporate tax base. If $\phi>0(\phi=1)$, the cost of contribution evasion is partially (entirely) eliminated. We do not consider the case when $\phi>1$. In other words, we restrict the firm to not manipulating profit for its own sake but only as a consequence of wage underreporting. ${ }^{3}$

As long as the firm engages in fraud in both bases, the total amount evaded is:

$$
E=\underbrace{\left(t_{s}+t_{e}+t_{p}\left(1-t_{e}\right)\right) u L^{*}}_{\text {PIT + total social security }}+\underbrace{t_{c} \phi\left(1+t_{s}\right) u L^{*}}_{\text {corporate tax }} .
$$

The firm's behaviour is constrained by the probability of detection and penalties that make evasion costly. Let the probability of detection be $\bar{p}=p_{1}\left(\phi\left(1+t_{s}\right) u L^{*}\right)+p_{2}\left(\frac{u}{w^{R}}\right)$, where $p_{1}($.$) is a function of the amount by which the firm adjusts its TI, in order to bring$ profit closer to its actual level. $p_{1}($.$) is the probability of being caught for cheating at$ the corporate tax base, while $p_{2}($.$) is the probability that the mechanism of contribution$ evasion is exposed. We follow Slemrod and Yitzhaki (2000) and assume an endogenous detection probability that is an increasing function of evaded income in the corporate tax base, so that $p_{1}^{\prime}\left(\phi\left(1+t_{s}\right) u L^{*}\right)>0 . p_{2}($.$) is a function of the ratio of the amount of$ wage underreported to the total wage and is also assumed to be increasing in the amount of wage underreported, $p_{2}^{\prime}\left(\frac{u}{w^{R}}\right)>0$. A firm that is paying contributions on minimum wages is more likely to attract attention than a firm paying the average wage for the economy. If $u=0$, then $p_{1}=p_{2}=0$, which captures our previous assumption that there will be no corporate income adjustment without contribution evasion. The firm is risk neutral. Its after-tax profit if not detected is:

$$
\begin{aligned}
\pi^{n d} & =Y\left(L^{*}\right)-w^{R} L^{*}-\left(w^{R}-u\right) t_{s} L^{*} \\
& -t_{c}\left[Y\left(L^{*}\right)-\left(w^{R}-u\right) L^{*}\left(1+t_{s}\right)-\phi u L^{*}\left(1+t_{s}\right)\right]
\end{aligned}
$$

For the determination of a penalty scheme, we assume that an audit performed for corporate tax evasion uncovers wage understatement and vice versa. An important question in this context is whether the firm will be reimbursed for its overpayment of profit (if any), not reimbursed, or penalised for engaging in evasion in general (Yaniv,

taxable income in previous years in expectation of the lower future rate. Regarding strategies for reducing sales, the most common one is not issuing an invoice, which makes a cash transaction untraceable.

${ }^{3}$ If a firm reports zero taxable income, then it completely removes the cost of social security evasion and the corporate income tax, although it faces a higher probability of audit. 
1988). In the first two cases - full or partial reimbursement and no reimbursement at all - the firm faces no penalty for manipulating profits provided that it is triggered by contribution evasion. Therefore, it pays off to set $\phi=1$. If not detected, the firm will have eliminated the cost of its contribution fraud partially or fully. If detected, it will be punished for payroll and personal income tax evasion, but not corporate profit understatement. Thus, even though the profit tax is overpaid, it makes sense not to reimburse the firm, but to punish it with a fraction of the tax "evaded". In a sense this would be a punishment for not overpaying CIT completely because, if this were the case, then no CIT "evasion" would have taken place. The penalty under these conditions becomes:

$$
P=\lambda_{1}\left(t_{s}+t_{e}+t_{p}\left(1-t_{e}\right)\right) u L^{*}+\lambda_{2} t_{c} \phi\left(1+t_{s}\right) u L^{*}
$$

where $\lambda_{1}>1$ and $\lambda_{2}<1 .^{4}$ In the event of detection, the firm's profit changes to:

$$
\begin{aligned}
\pi^{d} & =Y\left(L^{*}\right)-w^{R} L^{*}-\left(w^{R}-u\right) t_{s} L^{*} \\
& -t_{c}\left[Y\left(L^{*}\right)-\left(w^{R}-u\right) L^{*}\left(1+t_{s}\right)\right]-\lambda_{1}\left(t_{s}+t_{e}+t_{p}\left(1-t_{e}\right)\right) u L^{*} \\
& -\lambda_{2} t_{c} \phi\left(1+t_{s}\right) u L^{*} \\
& =\pi^{n d}-P
\end{aligned}
$$

An employer then chooses $\phi^{*}$, and $u^{*}$ to maximize expected profit:

$$
E[\pi]=(1-\bar{p}) \pi^{n d}+\bar{p} \pi^{d}
$$

The first-order conditions for this problem are:

$$
\begin{aligned}
& \frac{\partial E[\pi]}{\partial \phi}=t_{c}-p_{1}^{\prime} P-\left(p_{1}+p_{2}\right) \lambda_{2} t_{c}=0 \\
& \frac{\partial E[\pi]}{\partial u}=t_{s}-t_{c}\left(1+t_{s}\right)-\left(p_{1}+p_{2}\right) A-p_{2}^{\prime} \frac{1}{w^{R}} \frac{P}{L^{*}}=0,
\end{aligned}
$$

where $A=\lambda_{1}\left(t_{s}+t_{e}+t_{p}\left(1-t_{e}\right)\right)$.

As discussed above, the marginal cost of underreporting one dollar of profit, $\frac{p_{1}^{\prime} P}{1-\left(p_{1}+p_{2}\right) \lambda_{2}}$ is a function of both the probability of detection for profit manipulation $p_{1}$ as well as the probability of detection for contribution evasion $p_{2}$, and is equal to the marginal benefit,

\footnotetext{
${ }^{4} \mathrm{An}$ additional assumption behind this penalty structure is that the firm bears full responsibility for evaded employees' contributions. This possibility is not accounted for by the law, so we will ignore the fact that workers cooperate willingly.
} 
$t_{c}$. The second-order condition of (7) also imposes a restriction on $p_{1}^{\prime \prime}\left(\phi\left(1+t_{s}\right) u L^{*}\right) .^{5}$

It can be seen from (8) that the marginal benefit of underreporting wage by one dollar, $t_{s}$, equals the marginal cost of overreporting profit at the corporate tax base plus the expected penalty. We thus obtain the necessary condition for contribution evasion to be

$$
\frac{t_{s}}{\left(1+t_{s}\right)}>t_{c}
$$

which requires that the CIT is below the payroll rate.

Denote $E[\pi]=f$. Let $f_{\phi}$ and $f_{\phi \phi}$ be the first and second derivatives of $f$ with respect to $\phi$. Rewriting the FOC, totally differentiating them and dividing by $d t_{c}$, we obtain:

$$
\begin{aligned}
& f_{\phi \phi} \frac{d \phi}{d t_{c}}+f_{\phi u} \frac{d u}{d t_{c}}=-f_{\phi t_{c}} \\
& f_{u \phi} \frac{d \phi}{d t_{c}}+f_{u u} \frac{d u}{d t_{c}}=-f_{u t_{c}}
\end{aligned}
$$

where $d t_{s}=d t_{p}=d t_{p}=d \lambda_{1}=d \lambda_{2}=d w^{R}=0$, since we would like to consider only the effects of a change in $t_{c}$.

We use Cramer's rule to determine the sign of

$$
\frac{d u}{d t_{c}}=\frac{\operatorname{det}|B|}{\operatorname{det}|A|}
$$

where

$$
\operatorname{det}|A|=\operatorname{det}\left[\begin{array}{cc}
f_{\phi \phi} & f_{\phi u} \\
f_{u \phi} & f_{u u}
\end{array}\right]=f_{\phi \phi} f_{u u}-f_{\phi u}{ }^{2}>0^{6}
$$

and

$$
B=\left[\begin{array}{ll}
f_{\phi \phi} & -f_{\phi t_{c}} \\
f_{u \phi} & -f_{u t_{c}}
\end{array}\right] .
$$

It can be shown that $\operatorname{det}|B|<0$, so that $\frac{d u}{d t_{c}}<0$ (see Appendix II for derivations).

This negative relationship is not unexpected. A decrease in $t_{c}$ stimulates contribution evasion by decreasing both the marginal cost of reporting more profit and the expected penalty so that $\frac{d\left(w^{R}-u\right)}{d t_{c}}>0$. Thus, cutting the CIT rate can raise taxable income in

\footnotetext{
${ }^{5}$ The second-order condition is $-\left(1+t_{s}\right) u L^{*}\left(p_{1}^{\prime \prime}+2 p_{1}^{\prime} \lambda_{2} t_{c}\right)<0$ and holds if $p_{1}^{\prime \prime}>0$, i.e. if $p_{1}$ is convex. The second-order condition of (8) imposes the same restriction on $p_{2}, p_{2}^{\prime \prime}>0$

${ }^{6} f_{\phi \phi} f_{u u}-f_{\phi u}{ }^{2}>0$ is a sufficient condition for a relative maximum.
} 
the economy through two separate channels: First, a smaller rate translates into less corporate tax evasion; second, a lower rate triggers more social security evasion through the underreporting of wages with at least some firms overreporting corporate profits. Therefore, the policy of lowering the corporate tax burden may backfire through more evasion in another base.

Studying the effect of a change in $t_{s}$ on $w^{R}-u, w^{R}-u$ is decreasing in the payroll rate, again pointing to the fact that increasing the contribution burden may cause more wage underreporting. This is due to the positive sign of $\frac{d u}{d t_{s}}>0$ (Appendix II).

The relationships between the tax rates and $\phi$ are $\frac{d \phi}{d t_{c}}<0$ and $\frac{d \phi}{d t_{s}}>0$ and are derived with Cramer's rule in the same fashion as the relationship between $u, t_{c}$ and $t_{s}$ above. A decrease in $t_{c}$ leads to higher $\phi$ since, all else being equal, the firm has a stronger incentive to underreport wages, and therefore needs to manipulate profit more. A fall in $t_{s}$ lowers $\phi$ for precisely the opposite reason.

Lastly, we explore the effect of tax rates on taxable income. The TI that is going to be taxed at the corporate base is:

$$
T I=Y\left(L^{*}\right)-\left(w^{R}-u\right) L^{*}\left(1+t_{s}\right)-\phi u L^{*}\left(1+t_{s}\right)
$$

We ignore proceeds to the government from fines, as we are interested only in changes in revenue stemming from changes in taxable income.

$$
\frac{d T I}{d t_{c}}=\underbrace{\frac{\partial T I}{\partial \phi}}_{-} \underbrace{\frac{d \phi}{d t_{c}}}_{-}+\underbrace{\frac{\partial T I}{\partial u}}_{+} \underbrace{\frac{d u}{d t_{c}}}_{-}
$$

On the one hand, a lower CIT rate decreases TI because $\phi$ goes up. On the other hand, lower $t_{c}$ increases TI because $u$ increases, so the overall effect is ambiguous. Note that there will be a further effect - bigger incentive for honest reporting of profits unrelated to payroll tax evasion - which is not captured by the above formulation. The sign of $\frac{d T I}{d t_{s}}$ is also ambiguous. Decreasing $t_{s}$ raises taxable income because less payroll tax expense is deducted and because $\phi$ decreases, but $u$ goes down, shifting TI downwards.

$$
\frac{d T I}{d t_{s}}=\underbrace{\frac{\partial T I}{\partial t_{s}}}_{-}+\underbrace{\frac{\partial T I}{\partial \phi}}_{-} \underbrace{\frac{d \phi}{d t_{s}}}_{+}+\underbrace{\frac{\partial T I}{\partial u}}_{+} \underbrace{\frac{d u}{d t_{s}}}_{+}
$$

We therefore turn to the data to determine these relationships. Before that, we briefly describe the reforms in the two tax bases, on which we base our empirical analysis. 


\section{Institutional Background}

\subsection{Social security system: Reform and characteristics}

Until 1997 the social security system in Bulgaria was typical of any centrally planned economy: It was a standard pay-as-you-go (PAYGO) DB plan characterised by a loose linkage between benefits and contributions, too liberal conditions for access to the pension system, and an insurance burden borne solely by employers. By 1997 it became clear that a reform could no longer be postponed if the financial sustainability of the system was to be preserved (Shopov et al., 2005).

The changes led to the establishment of a three-pillar pension system known as the World Bank scheme, with the first pillar being the obligatory PAYGO. Some of the mandatory insurance contributions were redirected towards private occupational and eventually universal pension funds as well, which formed the basis of the second pillar, capital-based, with individual insurance accounts. The third pillar is a voluntary insurance system with people paying voluntary contributions into individual accounts. For a couple of years after its establishment the 2nd pillar was restricted to workers from the so-called first and second labour categories who paid contributions to occupational funds for supplementary pension and early retirement. People in these two categories are employed in hazardous conditions, such as miners, underground geologists, hydrologists and others (see Appendix I for a detailed classification).

Despite its fully funded structure, contributions to the second pillar are made only by employers. Note that in the empirical section of the paper, we do not take into account the part of the payroll rate that employers pay to 2nd Pillar Universal or Occupational funds, which is reported in Table 1 for the sake of completeness.

Workers in the three different labour categories face different payroll rates, with the first labour category having the highest rate due to the amount of risk involved in these professions. In 1999, for example, an employer had to pay $51.7 \%$ in payroll contributions for a first labour category worker, $46.7 \%$ and $36.7 \%$ for second and third labour category employees, respectively (Table 1). Over the years, these rates have decreased for employers as the social contribution burden was gradually shared with the workers.

Prior to 2000, the system did not distinguish between separate insurance risks. From 2000 onwards differentiated amounts of insurance contributions for pension, sickness and maternity, and work injury were introduced, with the employer and the employee sharing the contributions in a given ratio. The payroll contributions payable by employers in 1997 amounted to $42 \%$ of gross salary for workers in the third labour category. Four 


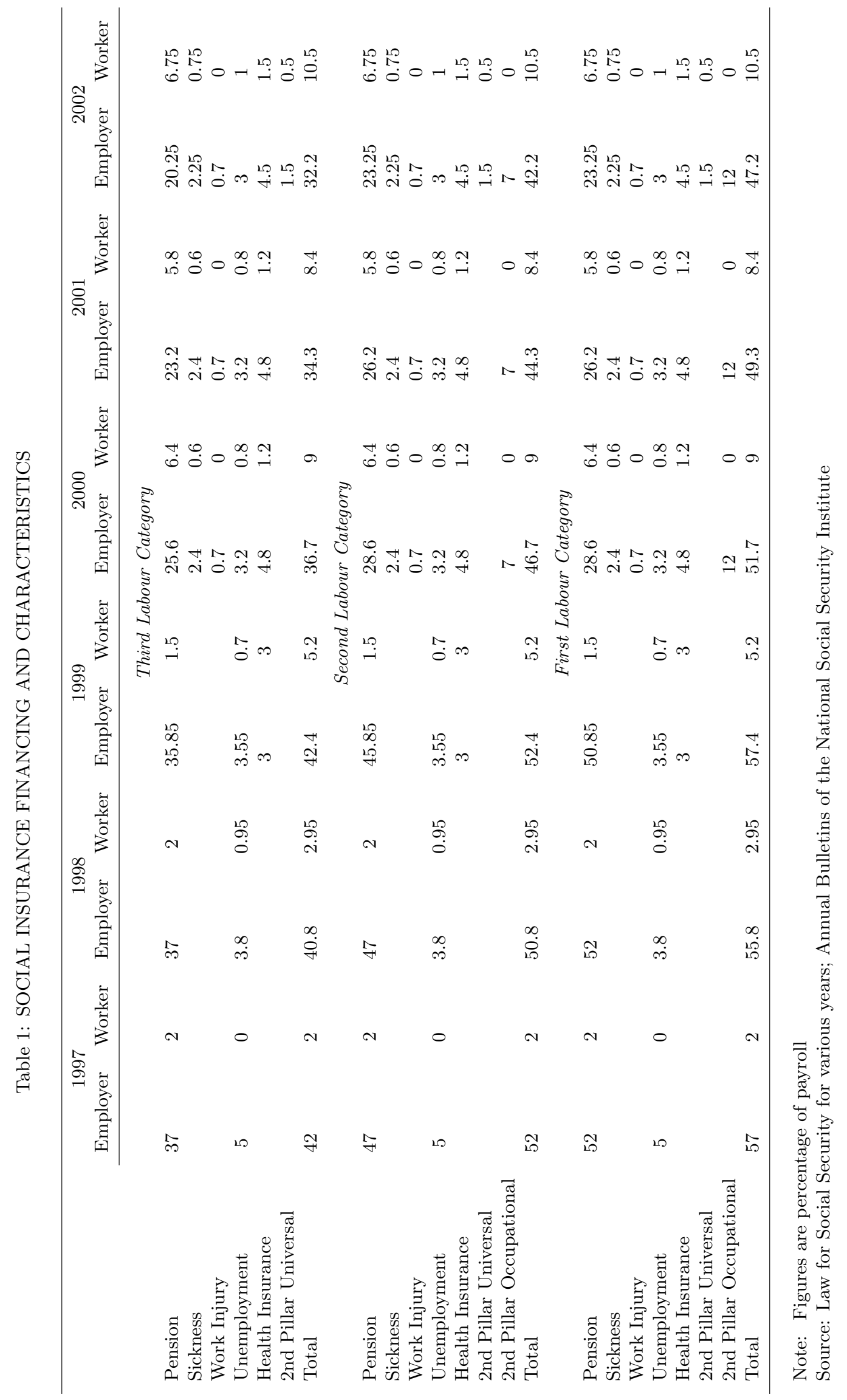


years later, in 2002, this percentage was $32.2 \%$. The combined employer-employee contribution rate decreased by only 3.3 percentage points for five years, from $44 \%$ in 1997 to $40.7 \%$ in 2002 .

The nature of the reform in the pension system was such that within a given year the difference between the payroll rates of the third and second labour categories remained fixed at 10 percentage points, while that between the second and first category remained 5 percentage points. Table 1 further shows that the payroll rates for the different labour categories changed by the same percentage points from year $t-1$ to year $t$. This means that the cross-sectional and time series variation in the payroll rates in absolute levels is the same for all three labour categories. Nevertheless, the percentage changes vary by labour category and over time, which allows us to identify the effect of the payroll rate on reported wages and taxable income using various econometric specifications.

\subsection{Corporate income tax}

Unlike the persistently high payroll tax rates, the tax rate on profit in Bulgaria has been lowered substantially over the years (Table 2). For the whole period 1997-2002 firms paid a tax on profits for the central budget and a tax on profit for municipalities - the municipality tax. The tax base for the municipality tax was taxable income, while the tax base for the tax on profit was the taxable income reduced by the amount of the municipality tax.

From 1997 to 2001 the standard CIT rate varied from $42.2 \%$ to $23.5 \%$, a change of 18.7 percentage points. Firms with taxable income below a legally stipulated threshold were subject to a lower preferential rate, which was less volatile than the standard rate and changed by about 10 percentage points in the period 1997-2002. It is important to point out that the system was not progressive, and firms subject to the standard rate did not pay the lower rate for profits up to the threshold. Starting in 2002, a single rate was imposed irrespective of firms' TI. Table 2 summarises the standard and preferential tax rates and shows the effective rate taking into account the local CIT surcharge.

The decrease in the CIT rates, however, was not accompanied by an extensive expansion of the tax base to make the reform revenue-neutral. Depreciation rates and loss carry-forwards remained unchanged throughout the 1997-2002 period (Table 2). Most importantly, while the definition of taxable income changed, its core elements remained the same. Taxable income is formed based on the transformation of the accounting financial result. The accounting financial result is the accounting value of the difference between revenues and expenses. Once this amount is determined, it is adjusted upwards 
Table 2: CORPORATE INCOME TAX FINANCING AND CHARACTERISTICS

\begin{tabular}{|c|c|c|c|c|c|c|}
\hline & 1997 & 1998 & 1999 & 2000 & 2001 & 2002 \\
\hline \multicolumn{7}{|l|}{ CIT rate central budget } \\
\hline TI $<$ Threshold (Preferential) & 26 & 20 & 20 & 20 & 15 & \\
\hline TI $>$ Threshold (Standard) & 36 & 30 & 27 & 25 & 20 & 15 \\
\hline CIT rate municipalities & 6.5 & 10 & 10 & 10 & 10 & 10 \\
\hline Total CIT rate (Preferential) & 33.4 & 28 & 28 & 28 & 23.5 & \\
\hline \multirow[t]{2}{*}{ Total CIT rate (Standard) } & 42.4 & 37 & 34.3 & 32.5 & 28 & 23.5 \\
\hline & \multicolumn{6}{|c|}{ Depreciation rates } \\
\hline Buildings & 4 & 4 & 4 & 4 & 4 & 4 \\
\hline Machines & 20 & 20 & 20 & 20 & 20 & 20 \\
\hline Vehicles & 8 & 8 & 8 & 8 & 8 & 8 \\
\hline All other assets & 15 & 15 & 15 & 15 & 15 & 15 \\
\hline Loss carry-forward (years) & 5 & 5 & 5 & 5 & 5 & 5 \\
\hline
\end{tabular}

Note: The threshold changed from 1997 to 1998 and remained the same from 1998 onward. In 2002 a single CIT rate was introduced irrespective of the level of taxable income.

Source: Law for Corporate Income Tax for various years

or downwards by certain provisions specified in the Corporate Income Tax Law for tax purposes in order to obtain TI. Therefore, any amendment to these provisions alters the definition of TI.

Table 3: CHANGES IN THE DEFINITION OF TAXABLE INCOME

\begin{tabular}{|c|c|c|c|c|c|c|}
\hline & 1997 & 1998 & 1999 & 2000 & 2001 & 2002 \\
\hline \multicolumn{7}{|l|}{ No. of provisions in the CIT Law } \\
\hline Increasing the financial result & 22 & 23 & 23 & 24 & 23 & 24 \\
\hline Decreasing the financial result & 11 & 10 & 15 & 13 & 14 & 17 \\
\hline \multicolumn{7}{|l|}{ No. of abolished provisions } \\
\hline Increasing the financial result & & 3 & 0 & 0 & 1 & 0 \\
\hline Decreasing the financial result & & 2 & 0 & 4 & 0 & 2 \\
\hline \multicolumn{7}{|c|}{ No. of newly stipulated provisions } \\
\hline Increasing the financial result & & 4 & 0 & 1 & 0 & 1 \\
\hline Decreasing the financial result & & 2 & 5 & 2 & 1 & 5 \\
\hline
\end{tabular}

Source: Law for Corporate Income Tax for various years

Table 3 shows how the number of provisions varied over the period of interest. In particular it shows how many provisions were abolished, how many new ones were introduced, and whether they increased or decreased TI. It is clear that the main change in the definition of TI occurred between 1997 and 1998 and since then the definition has 
mostly been altered with respect to the provisions that decrease TI. This means that an increase in reported taxable income, given falling CIT rates, will not be driven by expansions of the tax base.

\section{Empirical Analysis}

\subsection{Data description}

We use firm-level data for Bulgaria from the AMADEUS dataset provided by Bureau Van Dijk, which is a European electronic publishing firm. The data is an unbalanced panel consisting of firms' main financial statement variables. The period under consideration is restricted to 1997-2002 due to the introduction of so-called minimum social security thresholds in 2003 that legally stipulate the minimum wage level on which contributions are payable for every type of profession in a given industry. ${ }^{7}$

The main dependent variables of interest are the firm's total cost of employment (staf), which is the yearly amount paid in salaries and contributions, and corporate taxes paid (taxa), according to which we will assign each firm its respective tax rate and calculate TI (Table 4). The explanatory variables are firm size, measured by the amount of sales (turn); the number of employees, fixed assets and total assets, and the degree of indebtedness, which we capture by the amount of current liabilities (culi). We additionally control for changes in current assets (cuas).

Only firms that file a report at the end of the year are included in the panel. Firms in liquidation, dissolution, or bankruptcy are excluded from the analysis. Since sole traders are subject to special taxation, which is not part of the Corporate Law, they are not considered either. We have further excluded partnerships, cooperatives and other unincorporated entities, thus restricting the dataset to private and public limited liability companies (61\%) and one-person private and public limited liability companies (38\%). The remaining $1 \%$ of the firms in the data are branches of foreign companies and state companies.

If a firm has submitted both consolidated and unconsolidated financial statements, we consider only the unconsolidated one. Firms with missing values for both taxes paid and cost of employees for all years they appear in the panel, are dropped. We have further dropped observations with missing values of taxes paid, cost of employees,

\footnotetext{
${ }^{7}$ This provision does not leave much leeway for firms in terms of what wage to declare, although they still might be underreporting if the true wage of the employee is above the threshold. The minimum thresholds reflect the government's perception of what the true wages in the economy are (Slavova et al., 2007).
} 
Table 4: DESCRIPTIVE STATISTICS

\begin{tabular}{lcccccc}
\hline & 1997 & 1998 & 1999 & 2000 & 2001 & 2002 \\
& Mean & Mean & Mean & Mean & Mean & Mean \\
\cline { 2 - 6 } $\ln$ Wage & -4.11 & -3.96 & -4.25 & -4.20 & -4.21 & -4.05 \\
& $(1.17)$ & $(.975)$ & $(.807)$ & $(.787)$ & $(.755)$ & $(.849)$ \\
$\mathrm{TI}_{t}-\mathrm{TI}_{t-1}$ & & -1.05 & -.424 & -.055 & .071 & .087 \\
$\ln \left(1-\mathrm{t}_{s}\right)$ & & $(7.91)$ & $(5.22)$ & $(2.20)$ & $(2.02)$ & $(2.85)$ \\
& -.576 & -.552 & -.572 & -.462 & -.424 & -.370 \\
$\ln \left(1-\mathrm{t}_{c}\right)$ & $(.074)$ & $(.070)$ & $(.061)$ & $(.014)$ & $(.013)$ & $. .012)$ \\
& -.444 & -.273 & -.157 & -.148 & -.121 & -.135 \\
$\ln \left(\mathrm{t}_{s}-\mathrm{t}_{c}\right)$ & $(.203)$ & $(.179)$ & $(.173)$ & $(.169)$ & $(.139)$ & $(.133)$ \\
$\ln \left(1-\mathrm{t}_{s} / 1\right.$ - $\left.\mathrm{t}_{c}\right)$ & -1.69 & -1.96 & -1.35 & -1.66 & -1.59 & -1.89 \\
& $(.749)$ & $(.866)$ & $(.593)$ & $(.779)$ & $(.627)$ & $(.716)$ \\
$\ln ($ Fias/Toas $)$ & -.132 & -.279 & -.415 & -.314 & -.303 & -.234 \\
& $(.213)$ & $(.193)$ & $(.181)$ & $(.169)$ & $(.139)$ & $(.133)$ \\
$\ln ($ Turn/Toas $)$ & -.977 & -1.03 & -1.30 & -1.38 & -1.38 & -1.47 \\
& $(1.04)$ & $(1.04)$ & $(1.13)$ & $(1.18)$ & $(1.16)$ & $(1.23)$ \\
$\ln ($ Culi/Toas $)$ & $(1.15)$ & $(1.09)$ & $(1.22)$ & $(1.24)$ & $(1.18)$ & $(1.22)$ \\
$\ln ($ Cuas/Toas $)$ & -1.25 & -1.22 & -1.03 & -.971 & -.986 & -.944 \\
& $(1.02)$ & $(1.08)$ & $(1.12)$ & $(1.11)$ & $(1.12)$ & $(1.14)$ \\
$\mathrm{N}$ & -.995 & -.896 & -.689 & -.636 & -.632 & -.618 \\
& $(.872)$ & $(.796)$ & $(.822)$ & $(.785)$ & $(.782)$ & $(.785)$ \\
& 3,035 & 3,257 & 20,524 & 25,421 & 30,730 & 15,708 \\
\hline
\end{tabular}

Note: lnWage is the natural logarithm of reported wage per worker. The reported wage is obtained by dividing the total annual wage bill staf (wages + contributions) by $\left(1+\mathrm{t}_{s}\right)^{*} e m p l$, where $\mathrm{t}_{s}$ is the payroll tax rate and empl is the number of employees. $\mathrm{TI}_{t}-\mathrm{TI}_{t-1}$ is the first difference of taxable income and is in hundred thousands of Bulgarian levs; $\ln \left(1-t_{s}\right)$ is the natural log of the net-of-tax-share of the payroll tax rate; $\ln \left(1-t_{c}\right)$ is the natural $\log$ of the net-of-tax-share of the corporate tax rate; $\ln \left(t_{s}-t_{c}\right)$ is the natural $\log$ of the difference between the payroll and the corporate tax rates, while $\ln \left(1-\mathrm{t}_{s} / 1-\mathrm{t}_{c}\right)$ is the natural $\log$ of the ratio of the net-of-tax-shares of these two rates; $\ln$ (Fias/Toas) is the natural $\log$ of the ratio between fixed assets (tangible fixed assets + intangible fixed assets + other fixed assets, including financial fixed assets) and total assets; $\ln$ (Turn/Toas) is the natural log of the ratio between sales and total assets; $\ln$ (Culi/Toas) is the natural log of the ratio between current liabilities (loans + accounts payable + other current liabilities) and total assets; $\ln$ (Cuas/Toas) is the natural log of the ratio between current assets (stocks + accounts receivable+other current assets) and total assets. 
number of employees, total assets and fixed assets only at the beginning and the end of each panel.

We need to differentiate between firms based on their taxable income and the type of industry they operate in. For that purpose, we first recover TI from the data. We multiply the taxable income threshold stipulated by law with the lower CIT rate for a given year and assign firms that pay less than that amount in tax the low CIT rate, while those paying more are assigned the standard rate. This means that firms can switch between rates based on their annual income. Lastly, a zero corporate tax rate is assigned to those firms that have paid zero or have reported negative profit tax. Based on the differentiation between the corporate rates, we have some cross-sectional variation within a year and due to the continuous tax rate cuts, good overall time-series variation.

Once companies calculate their book profit, they have to add and deduct all items specified by law in order to obtain their taxable income. As a consequence, the data contains many firms that have zero or negative book profit but have paid positive tax. The converse is also true - some firms with positive profits for a given year pay no tax. Therefore, book profit can not be used in place of TI, nor is it a good indicator of it. For this reason, we recover TI by dividing the tax liability by the respective tax rate.

In view of the fact that the data do not provide information on losses carried forward, taxable income is probably adjusted downwards or becomes zero for some firms that have sustained losses in previous years. Another possibility why TI can deviate from the true tax liability are so-called deferred taxes. Hanlon (2003) provides a simple example of deferred taxes that arise as a result of tax differences, which in turn are due to, for example, different methods of depreciation used for book (straight line depreciation) and tax purposes (accelerated depreciation). Moreover, some firms may have made prepayments on current profits, and taxes paid in previous years have an impact on the current liability as well.

Intertemporal shifting of income within a base and between bases through avoidance and evasion mechanisms in anticipation of lower rates in the future can also affect the amount of reported taxable income in the current period. It is likely, therefore, that our measure of TI constitutes a rough approximation of real TI and hence there is measurement error in the explained variable. ${ }^{8}$ Despite the high probability of such an error, the estimated coefficients will not be biased, and the standard errors, while valid, will be larger due to the fact that the population variances of the coefficients are larger (Wooldridge, 2002).

\footnotetext{
${ }^{8}$ Hanlon (2003) provides an excellent analysis of the caveats in inferring taxable income from firms' financial statements.
} 
Social security rates are assigned to each firm depending on its type of industry. The payroll tax rate, therefore, varies between industries within a year and over time. Appendix I lists the industries that fall within the first and second labour category and are, as a consequence, liable to pay higher payroll contributions. On average within a given year, the share of firms in the first labour category is $1 \%$ of the sample, and that of the second labour category - $10 \%$ of the sample. The AMADEUS database provides firms' total cost of employment staf, which is the sum of wages and payroll taxes. We divide staf by $1+t_{s}$ and the number of employees in order to obtain the average reported annual wage bill per employee, $w^{R}$.

\subsection{Empirical specification}

In order to test if there is shifting of income out of social security into the corporate tax base as a result of a faster decreasing corporate tax rate than payroll rates, we employ the following basic specifications:

$$
\begin{aligned}
\ln \left(w_{i t}^{R}\right) & =\alpha_{0}+\alpha_{1} \ln \left(1-\left(t_{s}\right)_{i t}\right)+\alpha_{2} \ln \left(1-\left(t_{c}\right)_{i t}\right)+\epsilon_{i t} \\
D . T I_{i t} & =\beta_{0}+\beta_{1} D \cdot \ln \left(1-\left(t_{s}\right)_{i t}\right)+\beta_{2} D \cdot \ln \left(1-\left(t_{c}\right)_{i t}\right)+\delta,
\end{aligned}
$$

where $\ln \left(1-\left(t_{s}\right)_{i t}\right)$ and $\ln \left(1-\left(t_{c}\right)_{i t}\right)$ are the natural logarithms of the net-of-tax-shares of the payroll and corporate tax rates, respectively, in firm $i$ at time $t . \ln \left(w_{i t}^{R}\right)$ is the natural logarithm of the reported wage bill, while $D . T I_{i t}$ is the first-difference $T I_{i t}-T I_{i t-1}$ in absolute levels. Equations (15) and (16), where the two tax rates are entered separately into the wage and taxable income equations, most closely follow the model developed in Section 3. Our model predicts that an $\alpha_{1}>0$ and $\alpha_{2}<0$ would be indicative of shifting out of the payroll base, while we expect that $\beta_{2}>0$ in the TI equation.

Note that due to the very large number of firms reporting zero TI, we are not able to log-transform taxable income. Approximately $50 \%$ of firms bunch at the corner solution of zero TI. For example, $20 \%$ report TI=0 in 1997, and this percent grows to $60 \%$ in 2001. A logarithmic transformation of taxable income will automatically drop observations with zero taxable income, as $\log (0)$ is not defined. In effect we will be selecting on the dependent variable and use only those firms which have reported positive taxable income in the estimation. By dropping the zeros, the dependent variable would no longer be taxable income, but TI conditional on the firm realising any profit to be taxed $E(\ln (y) \mid x, y>0)$.

As an alternative to eqs. (15) and (16), we consider the effect of the tax wedge 
$\ln \left(t_{s}-t_{c}\right)$ or $\ln \left(\frac{1-t_{s}}{1-t_{c}}\right)$ on the two explained variables.

$$
\begin{aligned}
\ln \left(w_{i j t}^{R}\right) & =\gamma_{0}+\gamma_{1} \ln \left(\left(t_{s}\right)_{i t}-\left(t_{c}\right)_{i t}\right)+\epsilon_{i t}^{*} \\
D . T I_{i t} & =\sigma_{0}+\sigma_{1} D \cdot \log \left(\left(t_{s}\right)_{i t}-\left(t_{c}\right)_{i t}\right)+\delta^{*} .
\end{aligned}
$$

The tax wedge, which Gordon and Slemrod (2000) refer to as a "tax incentive term", is a measure of the incentives to engage in income shifting, given the difference between the rates in the two bases. Provided that there is shifting of income between the two bases, the reported wage should decrease as the difference between the payroll rate and CIT increases, which translates into $\gamma_{1}$ having a negative sign. If the increase in TI that stems from payroll tax evasion is completely overpaid in the corporate income tax base, we should observe a $\sigma_{1}>0$ and similar in absolute value to $\gamma_{1}$. In the model we have allowed firms to cook the books and choose not to overpay CIT, which is very likely to be happening in reality. Therefore, we expect that $\ln \left(t_{s}-t_{c}\right)$ will have a smaller effect on TI than on wages.

Given that we use net-of-tax-shares for our second definition of the tax wedge, the sign of $\ln \left(\frac{1-t_{s}}{1-t_{c}}\right)$ will be the opposite of that of $\ln \left(t_{s}-t_{c}\right)$. The limited variation in $\ln \left(1-t_{s}\right)$ from 2000 to 2002 means that the variation of $\ln \left(\frac{1-t_{s}}{1-t_{c}}\right)$ will be driven mostly by variation in $\ln \left(1-t_{c}\right)$ as exhibited by the identical standard errors of $\ln \left(\frac{1-t_{s}}{1-t_{c}}\right)$ and $\ln \left(1-t_{c}\right)$ for $2000-2002$ (Table 4$)$.

\subsection{Estimation issues}

There are several estimation problems with the specifications as presented thus far. First, $\ln \left(1-\left(t_{c}\right)_{i t}\right)$ is endogenous in the TI equations. While the CIT rate influences the amount of TI reported, it is TI that determines which corporate tax rate the firm is subject to. The solution of reverse causality in similar specifications has been the introduction of an instrument (IV), which is correlated with the endogenous variable, but exogenous to the error term (Gruber and Rauh, 2007; Gruber and Saez, 2002). We follow the literature and construct such an IV by keeping a firm's TI in year $t$ the same as in year $t-1$ and use only the changes in the tax law between the two years for identification. TI in year $t$ is also adjusted by growth rates, which are exogenous to the firm's behaviour and therefore show how TI would have grown in the absence of any interference by the company.

The growth rates are calculated in the following way: Apart from Bulgaria, we use 
data for the Czech Republic, Hungary, Poland, and Romania taken from the AMADEUS dataset for the period 1997-2002. Firms within each NACE2 industry are separated into taxable income deciles. TI for the Czech Republic, Hungary, Poland and Romania is calculated in the same way as that for Bulgaria - by dividing taxes paid by the statutory tax rate. Statutory tax rates for the four additional countries are taken from Ernst 8 Young Worldwide Corporate Tax Guides.

The growth rates of TI from year $t-1$ to year $t$ for each income decile within a given NACE2 industry is calculated for Poland, the Czech Republic, Hungary and Romania and averaged out. We then multiply the TI of Bulgarian firms in year $t-1$ by one plus the specific NACE2-TI income decile growth rate and apply the year $t$ tax rules to this adjusted TI. It is possible that the four countries we use may have had shocks affecting their industries differently; however, they were still in transition in the period we consider and coming out of a similar political and to some extent economic background as Bulgaria, albeit the Czech Republic and Hungary being much stronger and bigger economies.

The instrument for $\ln \left(1-\left(t_{c}\right)_{i t}\right)$ is thus $\ln \left(1-\left(t_{p}\right)_{i t}\right)$, which is the log of the predicted net-of-tax-share. The same logic applies for $\ln \left(\left(t_{s}\right)_{i t}-\left(t_{c}\right)_{i t}\right)$ and $\ln \frac{1-t_{s}}{1-t_{c}}$, which are instrumented with $\ln \left(\left(t_{s}\right)_{i t}-\left(t_{p}\right)_{i t}\right)$ and $\ln \frac{1-t_{s}}{1-t_{p}}$, respectively in the incentive-term specifications.

Second, the instruments above are constructed as a function of income in the previous period $t-1$. Thus, if $T I_{i t-1}$ is correlated with $\delta\left(\delta^{*}\right)$, running the regression with the IVs will still produce biased results. The two sources of endogeneity in this framework, as described by Gruber and Saez (2002), are mean reversion and changes in the income distribution. Mean reversion occurs when there are fluctuations in taxable income, which are transitory. For example, a firm that is exceptionally successful in year $t-1$ is likely to revert to its normal performance in year $t$. External shocks, which make some firms more profitable than others for reasons unrelated to changes in the tax rates, change the income distribution, which, if uncontrolled for, will bias estimation. To account for the possibility of different growth rates at different points in the income distribution, we include lagged taxable income as an explanatory variable in the TI equations.

Further, we follow Gruber and Saez (2002) and include an even richer specification of lagged taxable income to account for the possibility of a non-linear interaction between mean reversion and changes in the income distribution. In particular, we add a 10-piece spline of lagged taxable income, defined at the level of the entire sample, in the TI regressions. Nevertheless, we are still imposing the assumption that the yearly changes in mean reversion and the taxable income distribution are not correlated with the annual 
changes in tax policy.

Even with these controls, however, lagged taxable income can still be endogenous to the CIT rate change from year $t-1$ to year $t$ in the presence of income shifting. If firms expect a lower corporate tax rate in year $t$, then they have an incentive to report less TI in $t-1$ and more TI in $t$. Thus, falling CIT rates, or equivalently, increasing net-of-tax-shares from $t-1$ to $t$, can be accompanied by increasing taxable incomes due to income shifting. This, in return, can lead to upward bias in the estimates of the elasticity of TI w.r.t. the net-of-tax-share of the CIT rate.

Taxable income and wages of a firm can rise or fall from year to year for many different reasons apart from the corporate tax rate or income shifting. The firm, for example, can become more profitable because of increased management quality, local characteristics, or overall business strategy, and can consequently reward its employees better. Or it can change its financial policy, relying on more debt. Broadening of the tax base that offsets cuts in the statutory tax rate can be yet another reason.

We have shown in Table 3 that while the definition of taxable income has been changing over the years, as a whole the adjustments have narrowed the tax base, given the rising number of provisions decreasing the financial result. The depreciation rates for the different classes of assets have not changed and neither has the rule that firms can carry losses forward for 5 years. To control for unobserved firm-specific time-invariant heterogeneity, we first include firm fixed effects in the wage regressions, while differencing purges firm unobservable heterogeneity from the TI specifications. The assumption behind the within estimator is that the fixed effects $\alpha_{i}$ are correlated with the regressors $x_{i t}$. Accounting for firm fixed effects means that the effect of the two tax rates on taxable income and wages is identified only by the within-firm time-series variation in the tax rates.

Additionally, we include fixed assets and sales as a fraction of total assets in order to control for changes in profitability not related to changes in the tax rates. We further incorporate current liabilities divided by total assets to capture any adjustments in firms' short-term debt policy. Current assets are also controlled for.

Next, we add time fixed effects. In 1997 Bulgaria came out of an inflationary recession, and there was a change in government in 1998. It is therefore important to account for these elements in the variation, which are spuriously correlated with taxable income and wages by the inclusion of year dummies. Furthermore, since the minimum wage in the country was increasing on a yearly basis in the period under consideration, it affected the reported wage for these workers who truly earned the minimum wage or whose employers underreported their true wage to pay contributions on minimum wages. 
Thus, reported wages will increase due to legal provisions not related to the changes in the CIT or the payroll rates. This is yet another reason to include year fixed effects $\chi_{t}$.

By adding year dummies, the taxable income and wage response will be identified using only the cross-sectional variation in the tax rates. In fact, this framework is equivalent to the diff-in-diff estimator. To see this, note that first-differencing the data across time, $y_{i t}-y_{i t-1}$, eliminates the time-invariant firm fixed effects, but leaves the time-fixed effects. The time-fixed effects are dropped out if we difference again, this time across groups, i.e. transforming the data into $\left(y_{i t}-y_{i t-1}\right)-\left(y_{j t}-y_{j t-1}\right)$, which yields the difference-in-difference estimator.

Finally, we include industry-year fixed effects, which control for changes over time in factors common to all firms in a given industry such as regulation, industrial norms, etc.

We transform both regression frameworks to incorporate the changes discussed above. For example, equations (15) and (16) become:

$$
\begin{aligned}
\ln \left(w_{i t}^{R}\right) & =\alpha_{i}+\chi_{t}+\rho_{j t}+\alpha_{1} \ln \left(1-\left(t_{s}\right)_{i t}\right)+\alpha_{2} \ln \left(1-\left(t_{c}\right)_{i t}\right)+X^{\prime} \Delta+\epsilon_{i t} \\
D . T I_{i t} & =\chi_{t}+\rho_{j t}+\beta_{1} D \cdot \ln \left(1-\left(t_{s}\right)_{i t}\right)+\beta_{2} D \cdot \ln \left(1-\left(t_{c}\right)_{i t}\right) \\
& +\sum_{m=1}^{10} \theta_{3 m} S P L I N E_{m}\left(T I_{i t-1}\right)+D \cdot X^{\prime} \Delta+\delta
\end{aligned}
$$

where $\alpha_{i}, \chi_{t}$ and $\rho_{j t}$ are firm-, year-, and industry-year fixed effects, respectively. $X$ includes the natural logarithm of the ratios of sales/total assets (toas), current liabilities/toas, fixed assets/toas and current assets/toas.

\section{Results}

\subsection{Effect of tax rates on reported wages}

The basic estimates of the wage equation are presented in Table 5. All regressions are estimated with firm-fixed effects. Because we always cluster at firm level, standard errors are robust to the disturbances being heteroscedastic and autocorrelated.

Column (1) in Table 5 presents a regression of the log of wage on the log of the net-of-tax-shares of the corporate and payroll tax rates, without any other controls, apart from firm-fixed effects. The elasticity of reported wage with respect to the net-oftax-share of the corporate tax rate is estimated to be -0.122 , while the elasticity w.r.t. 
the net-of-tax-share of the payroll rate is 1.2. The signs of the two coefficients are in line with the predictions of our model: a negative and significant effect of the CIT rate net-of-tax-share on wages represents compelling evidence for income shifting, as it is difficult to explain otherwise why this tax rate has an effect on employees' compensation as reported by employers.

Column (2) allows for year dummies, $\chi_{t}$, and controls for firm-level factors, including the log of fixed assets, sales, current liabilities and current assets, all as a ratio of total assets. While still positive, the effect of the payroll rate is reduced to .016 and imprecisely estimated once year dummies are included in the regression. This is not surprising, as identification of the wage response in Column (2) comes solely from the cross-sectional variation in the tax rates. In Table 1 we explained that due to the nature of the pension reform, the payroll rate has limited cross-sectional variation. The coefficient of the CIT rate almost doubles to -0.238 and remains significant.

To purge the regressions from shocks common to all firms from the same industry in a given year, we have included industry-year fixed effects in Column (3). The elasticity of wage with respect to the net-of-tax-share of the CIT rate remains very similar to that in Column (2), but the coefficient on the payroll rate increases to .354 and becomes significant at the $5 \%$ level. Using both year- and industry-year fixed effects in Column (4) yields nearly identical estimates to the ones obtained with industry-year dummies only.

To show robustness, Columns (5)-(8) repeat the analysis of Columns (1)-(4) in firstdifferences (FD). The assumption behind the FD specifications is that the percentage change in the average wage per employee is a linear function of the percentage changes in the CIT and the payroll net-of-tax-shares. Column (5) repeats the simple specification in Column (1) in first-differences, producing very similar results.

Generally, the FD estimation yields less negative elasticity of wages w.r.t. the netof-tax-share of the CIT rate as compared to the specifications in levels. One possible explanation is that there is a delayed response of wages to changes in the CIT rate. The FD estimator uses the correlation between wages and CIT from year $t-1$ to $t$ only, while the fixed-effects estimator relates deviations from average wages to deviations from average net-of tax-share of CIT for all years. It is therefore likely that the fixed-effects estimator is more robust to delayed responsiveness. Conversely, the payroll rate has a greater effect on wages in the FD estimation, suggesting a quicker adjustment of wages to changes in the contribution rates.

In Column (9) we check how the FD results change when we expand the differencing window to $t-2$, thus focusing on longer-run responses. If firms' adjustment to changes 


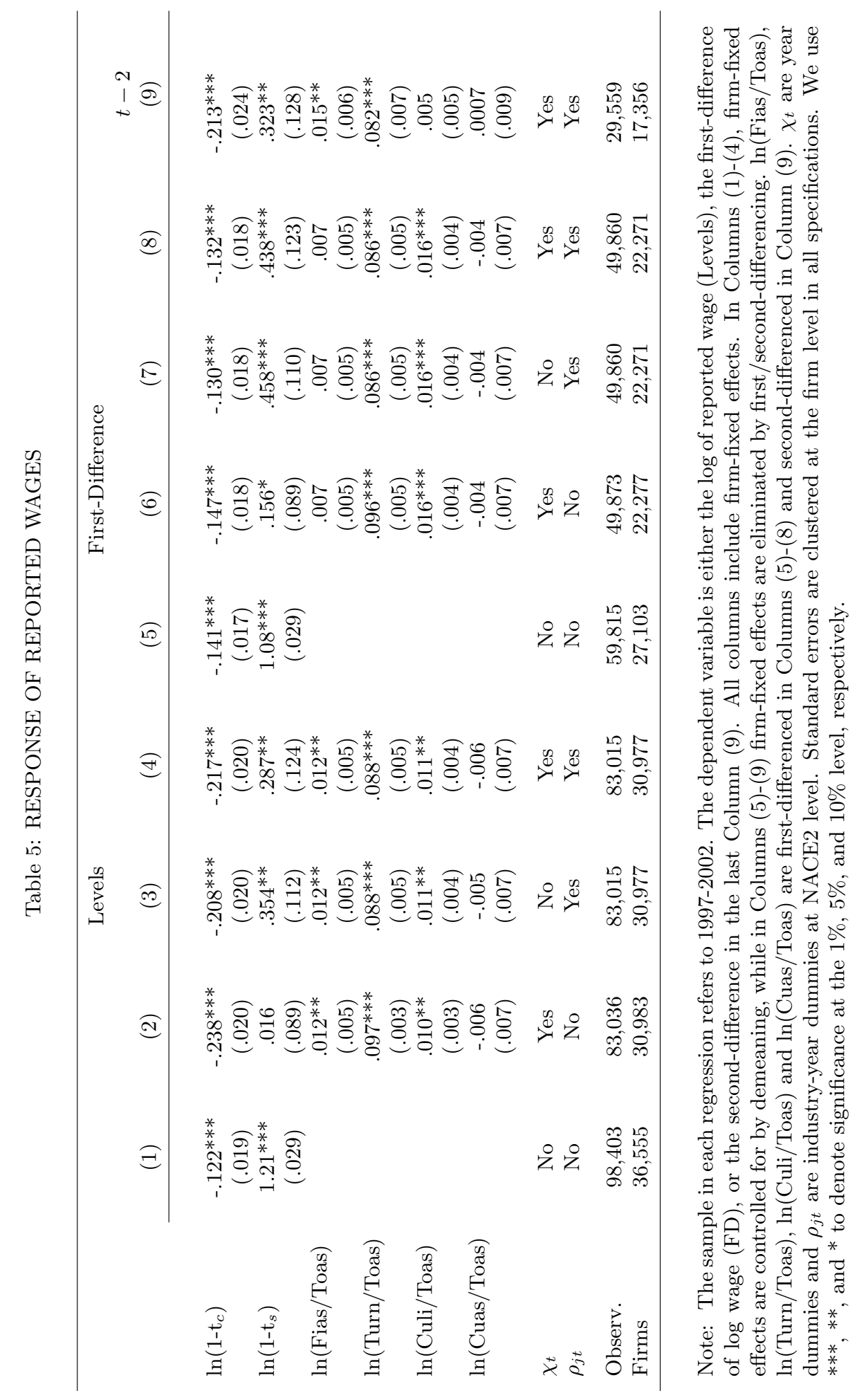


Table 6: RESPONSE OF REPORTED WAGES TO TAX WEDGE

\begin{tabular}{|c|c|c|c|c|c|c|c|c|}
\hline & \multicolumn{2}{|c|}{ Levels } & \multicolumn{2}{|c|}{ Levels } & \multicolumn{2}{|c|}{ FD } & \multicolumn{2}{|c|}{ FD $t-2$} \\
\hline & (1) & $(2)$ & $(3)$ & (4) & (5) & (6) & $(7)$ & (8) \\
\hline $\ln \frac{1-t_{s}}{1-t_{c}}$ & $\begin{array}{c}.229^{* * *} \\
(.020)\end{array}$ & & $\begin{array}{c}.218^{* * *} \\
(.020)\end{array}$ & & $\begin{array}{c}.136^{* * *} \\
(.018)\end{array}$ & & $\begin{array}{c}.216^{* * *} \\
(.024)\end{array}$ & \\
\hline $\ln \left(t_{s}-t_{c}\right)$ & & $\begin{array}{c}-.050 * * * \\
(.005)\end{array}$ & & $\begin{array}{c}-.046^{* * *} \\
(.004)\end{array}$ & & $\begin{array}{c}-.031^{* * *} \\
(.004)\end{array}$ & & $\begin{array}{c}-.049 * * * \\
(.005)\end{array}$ \\
\hline$\chi_{t}$ & & & & & & & & Yes \\
\hline$\rho_{j t}$ & & & & & & & & Yes \\
\hline Observ. & 83,036 & 81,208 & 83,015 & 81,188 & 49,860 & 48,462 & 29,559 & 27,829 \\
\hline Firms & 30,983 & 30,959 & 30,977 & 30,953 & 22,271 & 22,212 & 17,356 & 17,285 \\
\hline
\end{tabular}

Note: The sample in each regression refers to 1997-2002. The dependent variable is either the log of reported wage (Levels), the first-difference of the log wage (FD), or the second-difference. All columns include firm-fixed effects. We additionally control for $\ln$ (Fias/Toas), $\ln$ (Turn/Toas), $\ln$ (Culi/Toas) and $\ln$ (Cuas/Toas), which are not reported here and are first-differenced in Columns (5)-(8). Standard errors are clustered by firm in all specifications. $\chi_{t}$ are year dummies and $\rho_{j t}$ are industry-year dummies at NACE2 level. We use ${ }^{* * *}, * *$, and $*$ to denote significance at the $1 \%, 5 \%$, and $10 \%$ level, respectively.

in the tax rates is slow, as seems to be the case with the corporate tax rate, then there is a reason to expect that the $t-2$ estimates will be higher than the first-differenced ones. A quicker reaction to changes in rates or expectations that the rates will change in future will result in a weaker long-run response. In Column (9) the corporate rate effect is stronger for a longer difference window. In fact, the estimate is almost identical to that in Column (3). The coefficient on the payroll rate becomes 0.323, which is closer to the specification in levels.

Table 6 repeats the regressions from Table 5, but instead of estimating the effect of the tax rates separately, we include the tax wedge. The odd-numbered columns show the results for the ratio of the logs of the net-of-tax-shares, while the even-numbered columns contain the log of the difference $t_{s}-t_{c}$. Note the close resemblance of the absolute value of the coefficients and standard errors of $\ln \frac{1-t_{s}}{1-t_{c}}$ to those of $\ln \left(1-t_{c}\right)$ in Table 5. The reason is that the main part of the variation in the log-ratio of the netof-tax-shares stems from variation in the CIT rate. The effect of $\ln \left(t_{s}-t_{c}\right)$ on wages is -0.050 in the specification with year dummies only, and -0.046 when industry-year fixed effects are included. Similarly to Table 5, the first-difference estimation leads to lower estimates of the tax wedge in magnitude, driven by the slower responsiveness of wages to changes in the CIT rate. Once a longer difference window is taken in Columns (7)-(8), the estimates in FD are approximately the same as the estimates in levels. 
Table 7: RESPONSE OF REPORTED WAGES BY TAXABLE INCOME GROUPS

\begin{tabular}{|c|c|c|c|c|c|c|}
\hline \multirow{3}{*}{$\ln \left(1-\mathrm{t}_{c}\right)$} & \multicolumn{2}{|c|}{$\mathrm{TI}>\mathrm{T}$} & \multicolumn{2}{|c|}{$\mathrm{TI}<\mathrm{T}$ or $\mathrm{TI}=0$} & \multicolumn{2}{|c|}{$\mathrm{TI}<\mathrm{T}$ or $\mathrm{TI}>\mathrm{T}$ or $T I=0$} \\
\hline & $(1)$ & $(2)$ & $(3)$ & $(4)$ & (5) & $(6)$ \\
\hline & $\begin{array}{l}-.269 \\
(.831)\end{array}$ & & $\begin{array}{c}-.109 * * * \\
(.024)\end{array}$ & & $\begin{array}{c}-.329^{* * *} \\
(.040)\end{array}$ & \\
\hline $\ln \left(1-\mathrm{t}_{s}\right)$ & $\begin{array}{l}.879 * * \\
(.395)\end{array}$ & & $\begin{array}{c}.216 \\
(.141)\end{array}$ & & $\begin{array}{l}.457^{* *} \\
(.208)\end{array}$ & \\
\hline $\ln \left(t_{s}-t_{c}\right)$ & & $\begin{array}{l}-.083 \\
(.119)\end{array}$ & & $\begin{array}{c}-.029 * * * \\
(.005)\end{array}$ & & $\begin{array}{c}-.066^{* * *} \\
(.008)\end{array}$ \\
\hline Observ. & 3,643 & 3,392 & 61,235 & 61,235 & 18,137 & 16,561 \\
\hline Firms & 1,065 & 1,042 & 25,602 & 25,602 & 4,310 & 4,309 \\
\hline
\end{tabular}

Note: The sample in each regression refers to 1997-2002. The dependent variable is the log of reported wage. All columns include firm fixed effects and year-industry dummies, not reported. We additionally control for $\ln$ (Fias/Toas), $\ln$ (Turn/Toas), $\ln$ (Culi/Toas) and $\ln$ (Cuas/Toas), which are also not reported. Columns (1)-(2) pertain to firms that were subject to the standard tax rate (have taxable income above the legally stipulated threshold) for all years they appear in the panel. Columns (3)-(4) show results for firms who were subject to the lower corporate tax rate (have TI below the threshold) or reported zero taxable income for some of the years they appear in the panel. Columns (5)-(6) pertain to firms, which switched between high and low corporate tax rates or reported zero TI for some of the years they appear in the panel. Standard errors are clustered at firm level in all specifications. We use $* * *, * *$, and $*$ to denote significance at the $1 \%, 5 \%$, and $10 \%$ level, respectively.

Table 7 splits the sample into three groups based on taxable income. The first group is composed of firms that have consistently reported TI greater than the threshold, so that they are taxed at the standard CIT rate for all years they appear in the panel. The next group are firms who have always been subject to the lower rate, but may have reported zero taxable income for some of the years they are in the panel. Switchers between the high, low and zero CIT rates are included in the third group. The coefficients in each regression are comparable to those using the full sample in Table 5. Since the group with $\mathrm{TI}>\mathrm{T}$ has no cross-sectional variation in the CIT, Table 7 does not include year-fixed effects.

Interestingly, the effect of the tax wedge is higher for firms subject to the standard rate, albeit insignificant, and for switchers than it is for firms who were eligible for the lower CIT rate. Since the tax wedge is bigger for the low-CIT rate firms, we expected them to be more responsive to variations in the tax rates. However, it is possible that these businesses already pay wages close to the minimum wage and find it hard, therefore, to adjust the wage downward in response to changes in the tax wedge. Our inspection of the data confirmed that the average wage per employee in the group taxed at the standard CIT rate is at least three times as high as that for the low-CIT rate group. 
The wages reported by the switching firms seem to be most responsive to both tax rates, given the estimated coefficients. This high responsiveness is expected due to the fluctuations in the CIT rate that stem from variations in reported TI, confirming our hypothesis that firms adjust reported wages as the tax wedge changes. In the case of switchers, a $1 \%$ increase in the CIT's net-of tax-share reduces reported wages by $0.32 \%$, while an equivalent increase in the payroll's net-of-tax-share raises wages by $0.45 \%$.

\subsection{Effect of tax rates on reported taxable income}

If there is shifting of income out of the social security base due to payroll evasion, then to some extent part of this income should reappear as an increased corporate taxable profit. In Table 8 we turn to exploring what happens in the corporate tax base and to TI as a result of changes in the tax rates. The regressions present 2SLS estimation. All subsequent 2SLS regressions have very strong first stages with F-statistics for the coefficients of the IVs almost always around 1000 and above.

Since we have not log-transformed taxable income, the results are sensitive to outliers. We have restricted the first-difference of TI in the range $(-300,300)$, where TI is in hundred thousands of Bulgarian levs (BGN). ${ }^{9}$ This restriction drops 12 firms from the estimation, which have experienced great fluctuations in TI, mostly due to reporting huge TI in one year and zero TI the next year. ${ }^{10}$

In Column (1) we have included no controls for lagged income, and hence we do not account for mean reversion and changes in the income distribution. The results have the opposite sign for the CIT rate than expected. The estimates change dramatically, however, once lagged income is added in Column (2), which demonstrates the sensitivity of the results to controlling for first-period income. Lagged taxable income is significant with a coefficient -.281. If we consider the tax change from 1997 to 1998 for a firm in the second labour category subject to the standard CIT rate, then the coefficients in Column (2) imply that the 9 percent increase in the net-of-tax-share of the CIT rate in 1998 increased TI by 7,800 BGN $(\$ 3,900)$. The payroll net-of-tax-share is positive but is not significantly different from zero.

The estimate of the corporate net-of-tax-share increases considerably once we weaken

\footnotetext{
${ }^{9}$ All financial variables are in hundreds of thousands. The average exchange rate for the period 19972002 was $0.5 \$$ for 1 lev. We prefer to keep the variables in the original currency in order to avoid introducing error due to fluctuations in the exchange rate. The estimates for the CIT net-of-tax-share and the other explanatory variables are robust to different intervals, which remove the major outliers.

${ }^{10}$ Among these twelve companies are the Bulgarian Telecommunication Company, Lukoil Burgas, and five other major oil and energy producers, two copper extraction companies, a major shipping corporation, a chemical concern, and a sea resort joint stock company.
} 
Table 8: RESPONSE OF REPORTED TAXABLE INCOME

\begin{tabular}{|c|c|c|c|c|c|c|c|}
\hline & (1) & (2) & (3) & (4) & (5) & $\begin{array}{c}t-2 \\
(6)\end{array}$ & $\begin{array}{l}\text { Full } \\
(7)\end{array}$ \\
\hline $\ln \left(1-\mathrm{t}_{c}\right)$ & $\begin{array}{c}-2.30 * * * \\
(.375)\end{array}$ & $\begin{array}{l}.863^{*} \\
(.468)\end{array}$ & $\begin{array}{l}4.00^{* *} \\
(1.48)\end{array}$ & $\begin{array}{l}2.14^{*} \\
(1.13)\end{array}$ & $\begin{array}{c}2.31^{* *} \\
(1.16)\end{array}$ & $\begin{array}{l}4.91^{* *} \\
(1.60)\end{array}$ & $\begin{array}{c}4.57 \\
(3.07)\end{array}$ \\
\hline $\ln \left(1-\mathrm{t}_{s}\right)$ & $\begin{array}{c}1.43^{* *} \\
(.689)\end{array}$ & $\begin{array}{l}.417 \\
(.586)\end{array}$ & $\begin{array}{c}1.20 \\
(1.02)\end{array}$ & $\begin{array}{l}.151 \\
(1.15)\end{array}$ & $\begin{array}{l}-.256 \\
(1.42)\end{array}$ & $\begin{array}{l}-.867 \\
(1.66)\end{array}$ & $\begin{array}{l}-1.13 \\
(2.51)\end{array}$ \\
\hline $\ln$ (Fias/Toas) & $\begin{array}{l}-.014 \\
(.023)\end{array}$ & $\begin{array}{l}-.034^{*} \\
(.020)\end{array}$ & $\begin{array}{l}-.039^{*} \\
(.021)\end{array}$ & $\begin{array}{c}-.047^{* *} \\
(.020)\end{array}$ & $\begin{array}{c}-.048^{* *} \\
(.020)\end{array}$ & $\begin{array}{c}-.113^{* *} \\
(.037)\end{array}$ & $\begin{array}{l}-.165^{*} \\
(.092)\end{array}$ \\
\hline $\ln$ (Turn/Toas) & $\begin{array}{c}.211^{* * *} \\
(.037)\end{array}$ & $\begin{array}{c}.231^{* * *} \\
(.032)\end{array}$ & $\begin{array}{c}.293^{* * *} \\
(.044)\end{array}$ & $\begin{array}{c}.257^{* * *} \\
(.038)\end{array}$ & $\begin{array}{c}.260^{* * *} \\
(.038)\end{array}$ & $\begin{array}{c}.412^{* * *} \\
(.054)\end{array}$ & $\begin{array}{c}.381^{* * *} \\
(.090)\end{array}$ \\
\hline $\ln$ (Culi/Toas) & $\begin{array}{l}-.012 \\
(.023)\end{array}$ & $\begin{array}{c}-.061^{* *} \\
(.020)\end{array}$ & $\begin{array}{c}-.078^{* * *} \\
(.024)\end{array}$ & $\begin{array}{c}-.049^{* *} \\
(.021)\end{array}$ & $\begin{array}{c}-.050^{* *} \\
(.021)\end{array}$ & $\begin{array}{c}-.223^{* * *} \\
(.038)\end{array}$ & $\begin{array}{c}-.142^{* *} \\
(.051)\end{array}$ \\
\hline $\ln$ (Cuas/Toas) & $\begin{array}{c}.168^{* * *} \\
(.045)\end{array}$ & $\begin{array}{l}.125^{* *} \\
(.041)\end{array}$ & $\begin{array}{c}.163^{* * *} \\
(.043)\end{array}$ & $\begin{array}{l}.144^{* *} \\
(.043)\end{array}$ & $\begin{array}{c}.145^{* * * *} \\
(.043)\end{array}$ & $\begin{array}{l}.059 \\
(.061)\end{array}$ & $\begin{array}{l}.191 * * \\
(.075)\end{array}$ \\
\hline $\operatorname{lag} \mathrm{TI}$ & & $\begin{array}{c}-.281^{* * *} \\
(.044)\end{array}$ & & & & & \\
\hline Spline 5 & & & & & & $\begin{array}{c}-39.1^{* * *} \\
(11.79)\end{array}$ & \\
\hline Spline 6 & & & $\begin{array}{c}-21.58^{* *} \\
(7.52)\end{array}$ & $\begin{array}{c}-11.89^{* *} \\
(5.80)\end{array}$ & $\begin{array}{c}-12.74^{* *} \\
(5.95)\end{array}$ & $\begin{array}{l}7.58^{* *} \\
(2.43)\end{array}$ & $\begin{array}{c}-25.15^{*} \\
(14.78)\end{array}$ \\
\hline Spline 7 & & & $\begin{array}{c}4.96^{* * *} \\
(1.53)\end{array}$ & $\begin{array}{c}3.09^{* *} \\
(1.20)\end{array}$ & $\begin{array}{c}3.28^{* *} \\
(1.23)\end{array}$ & $\begin{array}{l}1.66^{*} \\
(.993)\end{array}$ & $\begin{array}{c}4.14 \\
(3.16)\end{array}$ \\
\hline Spline 8 & & & $\begin{array}{l}.089 \\
(.558)\end{array}$ & $\begin{array}{l}-.327 \\
(.501)\end{array}$ & $\begin{array}{l}-.297 \\
(.503)\end{array}$ & $\begin{array}{l}-.237 \\
(.573)\end{array}$ & $\begin{array}{l}2.66 \\
(2.02)\end{array}$ \\
\hline Spline 9 & & & $\begin{array}{l}.877 \\
(.593)\end{array}$ & $\begin{array}{l}1.01^{* *} \\
(.508)\end{array}$ & $\begin{array}{l}1.01^{* *} \\
(.509)\end{array}$ & $\begin{array}{l}1.16^{* *} \\
(.555)\end{array}$ & $\begin{array}{l}-2.24 \\
(2.15)\end{array}$ \\
\hline Spline 10 & & & $\begin{array}{c}-.284^{* * *} \\
(.046)\end{array}$ & $\begin{array}{c}-.280 * * * \\
(.043)\end{array}$ & $\begin{array}{c}-.280^{* * *} \\
(.043)\end{array}$ & $\begin{array}{c}-.529 * * * \\
(.058)\end{array}$ & $\begin{array}{l}-.076 \\
(.139)\end{array}$ \\
\hline$\chi_{t}$ & No & No & Yes & No & Yes & Yes & Yes \\
\hline$\rho_{j t}$ & No & No & No & Yes & Yes & Yes & Yes \\
\hline Observ. & 51,577 & 51,577 & 51,577 & 51,577 & 51,577 & 30,153 & 51,628 \\
\hline Firms & 22,434 & 22,434 & 22,434 & 22,434 & 22,434 & 17,354 & 22,446 \\
\hline
\end{tabular}

Note: The sample in each regression refers to 1997-2002. The dependent variable is the first-difference of taxable income in absolute levels; all $\ln ($.$) explanatory variables are also first-differenced. In Column (6)$ we use a longer differencing window and the spline is of $T I_{t-2}$. Estimates in Column (7) are based on the full sample, which includes the 12 outliers. $\chi_{t}$ are year dummies and $\rho_{j t}$ are industry-year dummies at NACE2 level. In all specifications, standard errors are clustered by firm. We use ${ }^{* * *}$, **, and ${ }^{*}$ to denote significance at the $1 \%, 5 \%$, and $10 \%$ level, respectively. 
the assumption that changes in the TI distribution are functions in log of lagged income. We do that by adding a 10-piece linear spline of lagged income in Column (3) with knots at the percentiles of the data. The first five splines drop out of the estimation because of the very big number of zeros of lagTI. The coefficient on the corporate rate goes up to 4.00 and remains significant. The payroll effect increases as well, but is again imprecisely estimated. The spline is very negative at the low end of the lagTI distribution, followed by several positive coefficients, increasing non-linearly as income rises.

Estimating the regression with year-industry fixed effects instead of year dummies yields a lower effect of $\ln \left(1-t_{c}\right)$ on D.TI (2.14) in Column (4). Column (5) combines year- and industry-year fixed effects leading to a very similar result to the one obtained with industry-year dummies only. Evaluating the tax change from 1997 to 1998 again, the coefficients in (5) imply a 20,800 BGN $(\$ 10,400)$ increase in TI in 1998 on average as a result of the $9 \%$ increase in CIT rate net-of-tax-share. To put this number into perspective, note that the average TI of the firms in the sample, excluding the 12 companies described above, is 95,600 BGN $(\$ 47,800)$.

The regression in Column (6) is identical to the one in Column (5), but we have second-differenced the data in order to check if TI adjusts immediately, or if its responsiveness is delayed. The estimate of the corporate net-of-tax-share more than doubles, rising to 4.91, and so do the coefficients of fixed assets, sales and current liabilities, suggesting that it takes time before firms adapt to changes in the tax policy. The effect of current assets, which is always positive and significant in the first-differenced specifications, becomes insignificant in second-differences.

Apart from Column (1), the payroll net-of-tax-share is found to have no significant effect on the first-difference of taxable income and is not robust to the dummy variables structure, being positive in Columns (1)-(4), and switching its sign in the remaining columns.

Lastly, Column (7) shows results for the unrestricted sample, which includes the 12 outliers we dropped before. While the corporate net-of-tax-share remains positive and similar in magnitude to the previous estimates, its standard error is much higher, resulting in imprecise estimation. The 12 outliers have a significant impact on the spline coefficients as well.

In Table 9 we focus on the response of taxable income to the tax wedge. Without lagged income control, the effect of the tax wedge has the wrong sign, which we have not reported. Once first period income is taken into account in Column (1), the estimates of the wedge become -.305 , and .265 for D. $\ln \frac{1-t_{s}}{1-t_{c}}$ and D. $\ln \left(t_{s}-t_{c}\right)$, respectively. The estimates of $\mathrm{D} . \ln \frac{1-t_{s}}{1-t_{c}}$ become more negative with the inclusion of the splines of lagged 
Table 9: RESPONSE OF REPORTED TAXABLE INCOME TO TAX WEDGE

\begin{tabular}{|c|c|c|c|c|c|c|c|c|}
\hline \multirow[b]{2}{*}{$\ln \frac{1-t_{s}}{1-t_{c}}$} & \multicolumn{2}{|c|}{ (1) } & \multicolumn{2}{|c|}{ (2) } & \multicolumn{2}{|c|}{ (3) } & \multicolumn{2}{|c|}{$\begin{array}{c}t-2 \\
(4)\end{array}$} \\
\hline & $\begin{array}{l}-.305 \\
(.310)\end{array}$ & & $\begin{array}{l}-1.00 \\
(.844)\end{array}$ & & $\begin{array}{l}-1.48 \\
(.908)\end{array}$ & & $\begin{array}{l}-2.37^{*} \\
(1.30)\end{array}$ & \\
\hline $\ln \left(t_{s}-t_{c}\right)$ & & $\begin{array}{l}.265^{* *} \\
(.120)\end{array}$ & & $\begin{array}{l}.316^{*} \\
(.180)\end{array}$ & & $\begin{array}{l}.303^{*} \\
(.172)\end{array}$ & & $\begin{array}{l}.279 \\
(.320)\end{array}$ \\
\hline $\operatorname{lagTI}$ & $\begin{array}{c}-.281^{* * *} \\
(.044)\end{array}$ & $\begin{array}{c}-.280 * * * \\
(.054)\end{array}$ & & & & & & \\
\hline$\chi_{t}$ & & & & & & & & \\
\hline$\rho_{j t}$ & & & & & & & & \\
\hline Observ. & 51,577 & 50,295 & 51,577 & 50,295 & 51,577 & 50,295 & 30,153 & 28,666 \\
\hline Firms & 22,434 & 22,564 & 22,434 & 22,564 & 22,434 & 22,564 & 17,354 & 17,425 \\
\hline
\end{tabular}

Note: The sample in each regression refers to 1997-2002. The dependent variable is either the firstdifference of TI in absolute levels, or the second-difference in Column (4). The net-of-tax-shares are also first-differenced. Columns (2)-(4) include splines of lagged TI, not reported here. We additionally control for D. $\ln$ (Fias/Toas), D. $\ln$ (Turn/Toas), D. $\ln$ (Culi/Toas) and D. $\ln$ (Cuas/Toas), which are also not reported. Standard errors are clustered by firm in all specifications. $\chi_{t}$ are year dummies and $\rho_{j t}$ are industry-year dummies at NACE2 level. We use ${ }^{* * *},{ }^{* *}$, and $*$ to denote significance at the $1 \%, 5 \%$, and $10 \%$ level, respectively.

TI in Columns (2)-(4), though not significant at conventional statistical levels, except in the second-differences estimation. Given the specification controlling for industry-year fixed effects, the $5.7 \%$ decrease in the net-of-tax-share of the wedge in 1998 is estimated to raise TI by $8,500 \mathrm{BGN}(\$ 4,250)$. This increase in TI is lower than the one obtained using the alternative definition of the wedge, $\ln \left(t_{s}-t_{c}\right):$ a $39 \%$ increase in the wedge in 1998 leads to 11,800 BGN $(\$ 5,900)$ increase in TI.

Overall, the coefficients suggest that TI is more responsive to the corporate netof-tax-share than the wedge, which makes sense, given that the wedge measures the incentives for income shifting out of the payroll base.

\section{Overall Effect on the Tax Base}

The firms in the sample paid $\$ 8.81$ billion in wages for the period $1997-2002$, and $\$ 3.48$ billion in social security contributions. Using the coefficients in Table 5, Column (4) and Table 8, Column (5), the changes in the net-of-tax-shares of the CIT and payroll rates for firms in a given labour category, given year, and standard, low or zero CIT rate, we estimate that if there were no cuts in the payroll rate for employers, reported wages 
would have decreased by $\$ 189.5$ million and contributions - by $\$ 68$ million. Conversely, had there been no cuts in the corporate income tax, reported wages could have risen by $\$ 138$ million and $\$ 52.2$ million more contributions could have been collected.

Taxable income declared for 1997-2002 was $\$ 6.9$ billion, of which $\$ 2.03$ billion was paid in corporate tax. This taxable income would have been $\$ 147.5$ million lower if the corporate tax rate was not cut, resulting in $\$ 60$ million less in corporate taxes.

All in all, the increase in the net-of-tax-share of the corporate tax rate had a positive result on the total tax base of wages and taxable income, decreasing wages by $\$ 138$ million, but increasing TI by $\$ 147.5$ million. Likewise, the net-of-tax-share of the payroll rate increases the total tax base by $\$ 189.5$ million through its impact on wages.

Another way to see the overall response is to estimate a regression for the total tax base, i.e. estimate the responsiveness of the sum of wages and taxable income to the net-of-tax-shares of the tax rates. This enables us to log-transform the dependent variable, as $\mathrm{TI}=0$ is no longer an issue. We instrument for $\ln \left(1-t_{c}\right)$ in the usual way. Since we cannot include a spline of taxable income only, we include a 10-piece spline of $\ln (\text { Wage }+\mathrm{TI})_{t-1}$ in a log-differenced 2SLS specification, in which we have included year-fixed effects and industry-year dummies.

The results of a full base regression are reported in Column (3) of Table 10 and confirm our previous calculations. The estimated elasticity of the CIT rate net-of-taxshare is positive, but not significantly different from zero. This is due to the opposing effects of the corporate tax on wages and taxable income, which leads to a limited response of the total tax base, even though $1-t_{c}$ has a non-trivial impact on the separate tax bases.

\section{Conclusion}

In the last decade many developing economies have resorted to cutting the corporate income tax rate in order to attract foreign direct investment and stimulate domestic business. Developed countries have followed suit in an attempt to prevent major outflows of capital due to intensified competition. While such policy clearly generates incentives towards more honest disclosure of corporate profits, it would be hasty to consider its effects in isolation from other tax bases within the economy. The main goal of our paper is to point out the risk that a too-low CIT can exacerbate payroll tax evasion if the contribution burden on employers is significant and payroll tax evasion is prevalent.

With the collaboration of employees, such fraudulent behaviour becomes virtually undetectable and as a consequence it may be more beneficial for a firm to overpay 
Table 10: RESPONSE OF THE TOTAL TAX BASE (WAGES+TAXABLE INCOME)

\begin{tabular}{lccc}
\hline & $\begin{array}{c}\text { lnWage } \\
(1)\end{array}$ & $\begin{array}{c}\text { D.TI } \\
(2)\end{array}$ & $\begin{array}{c}\text { D.ln(Wage+TI } \\
(3)\end{array}$ \\
\cline { 2 - 4 } $\ln \left(1-\mathrm{t}_{c}\right)$ & & & .349 \\
& $-.217^{* * *}$ & $2.31^{* *}$ & $(.228)$ \\
$\ln \left(1-\mathrm{t}_{s}\right)$ & $(.020)$ & $(1.16)$ & .128 \\
& $.287^{* *}$ & -.256 & $(.300)$ \\
Observ. & $(.124)$ & $(1.42)$ & 50,237 \\
Firms & 83,015 & 51,577 & 22,370 \\
\hline
\end{tabular}

Note: The sample in each regression refers to 1997-2002. Columns (1)-(2) repeat the estimates for the social security tax base from Table 5 and for the taxable income base from Table 8, respectively. Column (3) shows the results for the total tax base (wages + taxable income), estimated by log-differenced 2SLS regression. All regressions contain year- and industry-year fixed effects. Column (2) contains additionally a 10-piece spline of $\mathrm{TI}_{t-1}$, while Column (3) contains a 10-piece spline of $\ln (\text { Wage }+\mathrm{TI})_{t-1}$. Standard errors are clustered at firm level in all specifications. We use ${ }^{* * *},{ }^{* *}$, and $*$ to denote significance at the $1 \%, 5 \%$, and $10 \%$ level, respectively.

profit tax than to pay its full contribution expense. Thus, unless the government is able to somehow balance the corporate and social security burden, such a possibility certainly exists and should not be neglected. Given Europe's rapidly ageing population and significant reliance on defined benefit pension schemes, it is unlikely that we will witness a decrease of the social security burden on employers. It is therefore important to carefully consider not only the advantages of a low CIT rate, but also its potential side effects through its interaction with other tax bases. 


\section{References}

Allingham, M., Sandmo, A., 1972. Income tax evasion: A theoretical analysis. Journal of Public Economics 1, 323-338.

Bailey, C., Turner, J., 2001. Strategies to reduce contribution evasion in social security financing. World Development 29 (2), 385-393.

Cameron, A. C., Trivedi, P. K., 2009. Microeconometrics Using Stata. Stata Press, College Station, Texas.

Dimitrov, L., Gancheva, A., Pashev, K., 2004. The hidden economy in Bulgaria: Characteristics, structure and size. In: Iliev, P. (Ed.), The hidden economy in Bulgaria. Report, The Center for the Study of Democracy.

Ernst $\&$ Young, Various years. Worldwide Corporate Tax Guide. Ernst $\&$ Y Young.

Gillion, C., Turner, J., Bailey, C., Latulippe, D. (Eds.), 2000. Social security pensions. Development and reform. International Labour Office, Geneva.

Gordon, R., Slemrod, J., 2000. Are "real" responses to taxes simply income shifting between corporate and personal tax bases? In: Slemrod, J. (Ed.), Does Atlas shrug? The economic consequences of taxing the rich. Harvard University Press, pp. 240-280.

Gruber, J., Rauh, J., 2007. How elastic is the corporate income tax base? In: Auerbach, A., Hines, J., Slemrod, J. (Eds.), Taxing Corporate Income in the 21st Century. Cambridge University Press, pp. 140-163.

Gruber, J., Saez, E., 2002. The elasticity of taxable income: evidence and implications. Journal of Public Economics 84, 1-32.

Hanlon, M., 2003. What can we infer about a firm's taxable income from its financial statements? National Tax Journal 56 (4), 831-864.

Manchester, J., 1999. Compliance in social security systems around the world. In: Mitchell, O., Myers, R., Young, H. (Eds.), Prospects for social security reform. University of Pennsylvania Press, pp. 295-312.

McGillivray, W., 2001. Contribution evasion: Implications for social security pension schemes. International Social Security Review 54 (4), 3-22. 
Nyland, C., Smyth, R., Zhu, C. J., 2006. What determines the extent to which employers will comply with their social security obligations? Evidence from Chinese firm-level data. Social Policy and Administration 40 (2), 196-214.

Pashev, K., 2005. Corruption and tax compliance. Challenges to tax policy and administration. Report no.16, Center for the Study of Democracy.

Shopov, G., Noncheva, T., Tafradjiyski, B., 2005. The pension reform in Bulgaria: Bridging social policy research and policy making. Report, Club "Economika 2000".

Slavova, Z., Shisheva, M., Zlatanov, S., 2007. Social Security in Bulgaria in 2007. Annual report, National Social Security Institute.

Slemrod, J., Yitzhaki, S., 2000. Tax avoidance, evasion, and administration. NBER Working Paper W7473, National Bureau of Economic Research.

Wooldridge, J. M., 2002. Econometric analysis of cross section and panel data. MIT Press, Cambridge.

Yaniv, G., 1988. Withholding and non-withheld tax evasion. Journal of Public Economics $35,183-204$.

Yaniv, G., 1992. Collaborated employee-employer tax evasion. Public Finance/ Finances Publiques 47, 312-321.

Yaniv, G., 1993. Payroll tax evasion. Discussion Paper 51, National Insurance Institute.

\section{Appendix I: Classification of Firms into Labour Cate- gories}

Firms are assigned to labour categories in accordance with the Decree for the Categorization of Labour upon Retirement enacted at the end of 1997. The Decree stipulates the types of labour in the first, second and third labour categories, which pay different payroll contributions as described in Table 1.

The following type of labour falls within the First Labour Category:

Casting of metals

Metallurgy 
Manufacture of petroleum products and nuclear fuel

Mining

Quarrying

The following type of labour falls within the Second Labour Category:

Air, coastal, railway transport

Construction of ships, motorways, airfields, water projects, civil engineering works

Collection and treatment of sewage

Industrial dyeing (furs); Manufacture of pigments

Manufacture of glassware, plastics, rubber, ceramics, cement, explosives, weapons, fertilizers, glass fiber

The type of labour not specified under the first and second categories falls within the Third Labour Category

\section{Appendix II: Comparative Statics Derivations}

The two sufficient conditions for a relative maximum at a critical point are that $f_{\phi \phi}<0$ and $f_{\phi \phi} f_{u u}-f_{\phi u}{ }^{2}>0$. It follows from here that $f_{u u}<0$.

$f_{\phi u}=f_{u \phi}=-p_{1}^{\prime \prime}\left(1+t_{s}\right) \phi L^{*} P-p_{1}^{\prime}\left(\frac{P}{u}+\left(1+t_{s}\right) \phi L^{*} \lambda_{2} t_{c}\right)-p_{2}^{\prime} \frac{1}{w^{R}} \lambda 2 t_{c}<0$ due to $p_{1}^{\prime \prime}>0$ and $p_{2}^{\prime \prime}>0$. Similarly,

$f_{u t_{c}}=-\left(1+t_{s}\right)-p_{2}^{\prime} \frac{1}{w^{R}} \lambda 2 \phi u\left(1+t_{s}\right)<0$ and

$f_{\phi t_{s}}=-p_{1}^{\prime \prime} \phi u L^{*} P-p_{1}^{\prime} u L^{*}\left(\lambda_{1}+2 \lambda_{2} t_{c} \phi\right)<0$.

$$
\begin{aligned}
f_{\phi t_{c}} & =1-p_{1}^{\prime} \lambda_{2} \phi u L^{*}\left(1+t_{s}\right)-\left(p_{1}+p_{2}\right) \lambda_{2} \\
& =1-p_{1}^{\prime}\left(\frac{P}{t_{c}}-\frac{\lambda_{1}\left(t_{s}+t_{e}+t_{p}\left(1-t_{e}\right)\right) u L^{*}}{t_{c}}\right)-\left(p_{1}+p_{2}\right) \lambda_{2} \\
& =\frac{\lambda_{1}\left(t_{s}+t_{e}+t_{p}\left(1-t_{e}\right)\right) u L^{*}}{t_{c}}>0
\end{aligned}
$$

$f_{u t_{s}}=1-t_{c}-p_{1}^{\prime} \phi u L^{*} A-\left(p_{1}+p_{2}\right) \lambda_{1}-p_{2}^{\prime} \frac{1}{w^{R}}\left(\lambda_{1} u+\lambda_{2} t_{c} \phi u\right)$. Dividing (8) by $t_{s}$, we get $1-t_{c}=\frac{t_{c}}{t_{s}}+\left(p_{1}+p_{2}\right) \frac{A}{t_{s}}-p^{\prime} 2 \frac{1}{w^{R} t_{s}} P / L^{*}$. We plug the expression for $1-t_{c}$ into $f_{u t_{s}}$ to obtain: 


$$
\begin{aligned}
f_{u t_{s}} & =\frac{t_{c}}{t_{s}}+\left(p_{1}+p_{2}\right) \lambda_{1}+\left(p_{1}+p_{2}\right) \lambda_{1} \frac{t_{e}+t_{p}\left(1-t_{e}\right)}{t_{s}}+p^{\prime} 2 \frac{1}{w^{R}} \lambda_{1} u \\
& +p^{\prime} 2 \frac{1}{w^{R}} \frac{t_{e}+t_{p}\left(1-t_{e}\right)}{t_{s}}+p^{\prime} 2 \frac{1}{w^{R}} \frac{\lambda_{2} t_{c} \phi u}{t_{s}}+p^{\prime} 2 \frac{1}{w^{R}} \lambda_{2} t_{c} \phi u \\
& -\left(p_{1}+p_{2}\right) \lambda_{1}-p^{\prime} 2 \frac{1}{w^{R}} \lambda_{1} u-p^{\prime} 2 \frac{1}{w^{R}} \lambda_{2} t_{c} \phi u-p_{1}^{\prime} \phi u L^{*} A \\
& =\frac{t_{c}}{t_{s}}+\underbrace{\left(p_{1}+p_{2}\right) \lambda_{1} \frac{t_{e}+t_{p}\left(1-t_{e}\right)}{t_{s}}+p^{\prime} 2 \frac{1}{w^{R}} \frac{t_{e}+t_{p}\left(1-t_{e}\right)}{t_{s}}+p^{\prime} 2 \frac{1}{w^{R}} \frac{\lambda_{2} t_{c} \phi u}{t_{s}}}_{h>0} \\
& -p_{1}^{\prime} \phi\left(P-\lambda_{2} t_{c} \phi u L^{*}\left(1+t_{s}\right)\right) \\
& =\frac{t_{c}}{t_{s}}+h+p_{1}^{\prime} \phi \lambda_{2} t_{c} \phi u L^{*}\left(1+t_{s}\right)-\phi\left(t_{c}-\left(p_{1}+p_{2}\right) \lambda_{2} t_{c}\right) \\
& =h+p_{1}^{\prime} \phi \lambda_{2} t_{c} \phi u L^{*}\left(1+t_{s}\right)+\phi\left(p_{1}+p_{2}\right) \lambda_{2} t_{c}+t_{c}\left(1 / t_{s}-\phi\right)>0
\end{aligned}
$$

since $t_{s}<1$ and $\phi \leq 1$.

The main relationships are $\frac{d u}{d t_{c}}=\frac{\operatorname{det}|B|}{\operatorname{det}|A|}<0, \frac{d u}{d t_{s}}=\frac{\operatorname{det}|C|}{\operatorname{det}|A|}>0, \frac{d \phi}{d t_{c}}=\frac{\operatorname{det}|D|}{\operatorname{det}|A|}<0$ and $\frac{d \phi}{d t_{s}}=\frac{\operatorname{det}|E|}{\operatorname{det}|A|}>0$ and follow from:

$$
\begin{gathered}
\operatorname{det}|A|=\operatorname{det}\left[\begin{array}{ll}
f_{\phi \phi} & f_{\phi u} \\
f_{u \phi} & f_{u u}
\end{array}\right]>0 \\
\operatorname{det}|B|=\operatorname{det}\left[\begin{array}{ll}
f_{\phi \phi} & -f_{\phi t_{c}} \\
f_{u \phi} & -f_{u t_{c}}
\end{array}\right]=-f_{\phi \phi} f_{u t_{c}}+f_{\phi t_{c}} f_{u \phi}<0 \\
\operatorname{det}|C|=\operatorname{det}\left[\begin{array}{ll}
f_{\phi \phi} & -f_{\phi t_{s}} \\
f_{u \phi} & -f_{u t_{s}}
\end{array}\right]=-f_{\phi \phi} f_{u t_{s}}+f_{\phi t_{s}} f_{u \phi}>0 \\
\operatorname{det}|D|=\operatorname{det}\left[\begin{array}{ll}
f_{\phi u} & -f_{\phi t_{c}} \\
f_{u u} & -f_{u t_{c}}
\end{array}\right]=-f_{\phi u} f_{u t_{c}}+f_{\phi t_{c}} f_{u u}<0 \\
\operatorname{det}|E|=\operatorname{det}\left[\begin{array}{ll}
f_{\phi u} & -f_{\phi t_{s}} \\
f_{u u} & -f_{u t_{s}}
\end{array}\right]=-f_{\phi u} f_{u t_{s}}+f_{\phi t_{s}} f_{u u}>0
\end{gathered}
$$




\section{Working Paper Series}

ISSN 1211-3298

Registration No. (Ministry of Culture): E 19443

Individual researchers, as well as the on-line and printed versions of the CERGE-EI Working Papers (including their dissemination) were supported from the European Structural Fund (within the Operational Programme Prague Adaptability), the budget of the City of Prague, the Czech Republic's state budget and the following institutional grants:

- Center of Advanced Political Economy Research [Centrum pro pokročilá politickoekonomická studia], No. LC542, (2005-2011);

- Economic Aspects of EU and EMU Entry [Ekonomické aspekty vstupu do Evropské unie a Evropské měnové unie], No. AVOZ70850503, (2005-2011);

- Economic Impact of European Integration on the Czech Republic [Ekonomické dopady evropské integrace na ČR], No. MSM0021620846, (2005-2011);

Specific research support and/or other grants the researchers/publications benefited from are acknowledged at the beginning of the Paper.

(c) Boryana Madzharova, 2011

All rights reserved. No part of this publication may be reproduced, stored in a retrieval system or transmitted in any form or by any means, electronic, mechanical or photocopying, recording, or otherwise without the prior permission of the publisher.

Published by

Charles University in Prague, Center for Economic Research and Graduate Education (CERGE) and

Economics Institute ASCR, v. v. i. (EI)

CERGE-EI, Politických vězňů 7, 11121 Prague 1, tel.: +420 224005 153, Czech Republic.

Printed by CERGE-EI, Prague

Subscription: CERGE-EI homepage: http://www.cerge-ei.cz

Phone: + 420224005153

Email: office@cerge-ei.cz

Web: http://www.cerge-ei.cz

Editor: Michal Kejak

Editorial board: Jan Kmenta, Randall Filer, Petr Zemčík

The paper is available online at http://www.cerge-ei.cz/publications/working_papers/.

ISBN 978-80-7343-251-5 (Univerzita Karlova. Centrum pro ekonomický výzkum a doktorské studium)

ISBN 978-80-7344-243-9 (Národohospodářský ústav AV ČR, v. v. i.) 
CERGE-EI

P.O.BOX 882

Politických vězňů 7

11121 Praha 1

Czech Republic http://www.cerge-ei.cz 